\title{
Enkedronning Dorotheas og hertug Hans den Yngres kamp for kirkehøjheden over Als og Arø 1566-1622
}

\section{af Karsten Hermansen}

Fra 1559 til 1622 var først enkedronning Dorothea og derefter sønnen Hans den Yngre den lokale verdslige øvrighed for Sundeved, Als og Ærø. De stræbte begge efter den fulde suverænitet, også når det gjaldt kirkestyret. Men det gav konflikter med kongemagten, fordi Als og Ærø hørte under Odense Stift i kongeriget. Cand. phil. Karsten Hermansen belyser her den langstrakte strid mellem hertug og konge.

\section{Baggrund}

Odense Stift omfattede - $\mathrm{i}$ hvert fald fra midten af det 11 . århundrede - Fyn, Lolland, Falster, Langeland, Taasinge, Als, Arø og Femern. Als og \#rø blev gennem hele middelalderen bevaret som en del af Odense Stift, og danske kirkelove gjaldt her som i de øvrige danske stifter. ${ }^{1}$ Senere blev øerne en del af hertugdømmet Slesvig, hvor der gjaldt andre love - kirkelige såvel som verdslige - men tilknytningen til Odense Stift fortsatte. Denne sammenblanding af den kongerigske og slesvigske lovgivning skulle imidlertid vise sig at rumme stof til en langvarig konflikt om kirkehøjheden.

Reformationen i Danmark havde sit udspring i Sønderjylland. Frederik Is søn, den senere Christian III (1503-1559), fik i 1525 Haderslev Amt og Tørning Len overladt til underhold. Den unge hertug gik ivrigt ind for den evangeliske kristendomsopfattelse og skabte i 1528 som den første i Norden en luthersk fyrstekirke: paven som øverste kirkelige myndighed blev erstattet af hertug Christian, og præsterne blev dermed embedsmænd under hertugen. ${ }^{2}$

Ved traktaten i 1544 deltes hertugdømmerne mellem de tre brødre: Hans den Ældre (1521-1580), Adolf (1526-1586) og Christian III. Christian III valgte den sønderborgske del, bestående af Als, Ærø, Sundeved, Flensborg by og amt med Nørre Gøs herred (Bredsted landskab) samt Ryd Kloster. ${ }^{3}$ Christian IIIs brødre arbejdede - trods delingstraktatens tavshed herom ${ }^{4}$ - ivrigt på at erhverve den fulde kirkelige jurisdiktion i deres områder, ligesom Christian III tidligere havde haft den i Haderslev Amt og Tørning Len. ${ }^{5}$ 
Med Christian IIIs søn, hertug Hans den Yngre (1545-1622), startede endnu en strid om den gejstlige jurisdiktion. Ved arvedelingen i 1564 fik Hans den Yngre overladt Sønderborg og Nordborg med Ærø. Striden kom derfor til at handle om, hvorvidt Als og Ærø skulle bevare sin gamle kirkelige tilknytning til Odense Stift og dermed kongen.

Striden tog sin begyndelse, da Hans den Yngres mor, enkedronning Dorothea (1511-1571) i juni 1566 udnævnte sin egen provst over Als og Sundeved. Hans den Yngre tog tråden op og forfulgte sagen i årevis, først med broderen Frederik II og sidenhen med Christian IV (1577-1648).

Der er igennem årene givet en række forskellige forklaringer på kirkehøjhedsstriden mellem hertug og konge, men en samlet undersøgelse foreligger ikke. $^{6}$ Formålet med nærværende fremstilling er derfor at klarlægge sagens udvikling og forklare, hvorfor denne sag igen og igen blussede op $\mathrm{i}$ årene efter 1566. Skyldtes striden ønsket om fuld suverænitet i eget område, både i gejstlig og verdslig forstand? Var det udtryk for mindreværdskomplekser - på grund af Hans den Yngres stilling som »afdelt herre«? Gav hertugens tyske baggrund et tids- og miljø-bestemt behov for at erhverve kirkehøjheden?

Striden er interessant, da den ikke alene havde en konkret betydning for Hans den Yngre, men også fik principiel jurisdiktionel betydning for eftertidens småhertuger. Sagen eksemplificerer problemerne ved den blandede jurisdiktion. Disse problemer var på sin vis aktuelle helt frem til 1864. Derved bliver sagen et vigtigt eksempel på de danske kongers politik overfor hertugdømmerne.

\section{Enkedronning Dorothea}

Hertug Magnus af Sachsen-Lauenburgs datter, Dorothea, blev i 1525 - 14 år gammel - gift med hertug Christian, den senere Christian III. Dorothea havde ligesom sin mand en stærk luthersk tro og en meget stædig og vedholdende karakter. Kongeparret fik fem børn: Anna (1532-1585), Frederik II (15341588), Magnus (1540-83), Hans den Yngre (1545-1622) og Dorothea (15461617). ${ }^{7}$ Disse blev alle opdraget $\mathrm{i}$ en stærk religiøs ånd.

Efter Christian IIIs død i 1559 tog enkedronningen ophold på Koldinghus. Hun havde som livgeding fået Koldinghus med tilhørende len, herreder og gårde, Aakjær Gaard og Len, Randersgaard eller Dronningborg, Torup, Østrup og Essenbæk, byerne Kolding og Randers med al rente, indkomst og byskat, men ikke told. Sønderborg og Nordborg på Als fik hun også. Kongetienden af kirkegodset samt sognekirker, kapitels- og vikarie-gods forbeholdtes imidlertid kronen. ${ }^{8}$

Efter kongens død havde hun samme år planer om et ægteskab med svogeren hertug Hans den Fldre i Haderslev. Det blev ikke til noget som følge af 


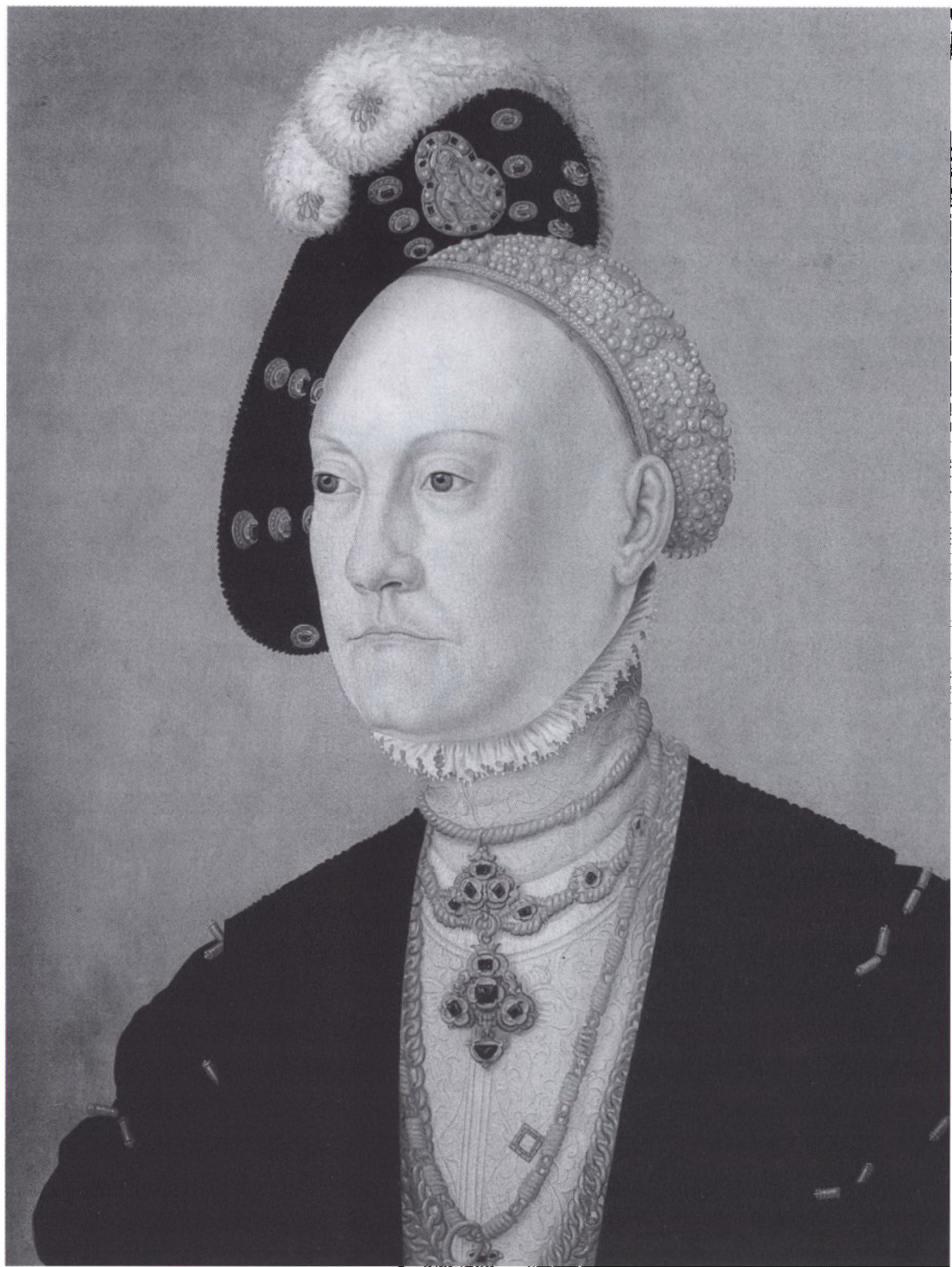

Christian III's dronning Dorothea (1511-1571) var en egenradig dame. Hun havde en stark luthersk tro, som dog ikke hindrede hende $i$ at fore en handfast politik for at sikre yndlingssonnen Hans den Yngres fyrstelige rettigheder. Maleri pd Frederiksborgmuseet, kopi efter Jacob Binck. Foto: Hans Petersen. 
modstand blandt de tyske teologer. I 1567 var spørgsmålet oppe at vende igen, men uden resultat. ${ }^{9}$ Enkedronningen var så sparsommelig, at det nærmest lignede nærighed. Til gengæld brugte hun penge på at være godgørende mod de fattige, ligesom hun ikke gik af vejen for at hjæalpe sine undersåtter, hvis de blev uretfærdigt behandlet. ${ }^{10}$ Sommeren 1570 flyttede Dorothea fra Koldinghus på grund af ombygning og slog sig ned hos sønnen Hans den Yngre og hans familie på Sønderborg Slot. Her boede hun til sin død den 7. oktober 1571.

\section{Hertug Hans den Yngre}

Hans den Yngre blev født den 25. marts 1545 på Koldinghus. Tilnavnet »den Yngre« fik han til forskel fra farbroderen Hans den Eldre. Da Christian III døde i 1559, blev enkedronningen Hans den Yngres formynder, og hun blev til sin død aldeles dominerende i den unge hertugs liv. ${ }^{11}$

Den 27. januar 1564 blev der foretaget en arvedeling til fordel for Hans den Yngre. Den unge hertug fik med det samme overladt Ahrensbök i Holsten, medens han først ville få Sønderborg og Nordborg efter moderens død og Plön, når hans farmoder, Frederik Is enke, Sophie, var død (hvilket skete 13. maj 1568). I tiden indtil de to damer døde skulle hertugen have henholdsvis 8.000 og 1.396 mark lybsk årligt. I 1582 fik Hans den Yngre desuden klostrene Reinfeld ved Lübeck og Ryd syd for Flensborg fjord som arv efter Hans den Fldre, der døde i 1580 . Helt uventet nægtede stænderne 2. oktober 1564 at hylde Hans den Yngre, hvorved han udelukkedes fra hertugdømmernes fællesregering, som bestod af hans to farbrødre, Hans den Fldre i Haderslev og Adolf på Gottorp samt Frederik II.

Hans den Yngre bekymrede sig dog ikke synderligt om sin hertugrolle i de første år. Større indtryk gjorde en rejse i 1565-66. Den unge hertug besøgte sin svoger, kurfyrst August af Sachsen, og var sammen med ham til rigsdagen i Augsburg i april 1566.

Enkedronningen var nok ik ke uden andel i et snildt arrangeret møde mellem Hans den Yngre og Elizabeth (født 20. marts 1550) - datter af afdøde Ernst af Braunschweig-Lüneburg-Grubenhagen og Margaretha af Pommern. Frederik II var lidt irriteret over ikke at være spurgt til råds i sin egenskab af familieoverhoved, men godkendte alligevel ægteskabskontrakten, der blev underskrevet 4. april 1568 i Braunschweig. Elizabeth fik en medgift på 10.000 gylden og løfte om en arv fra sin mor på 30.000 daler. Brylluppet fandt sted 19. september 1568 i Kolding. Frederik II måtte på grund af Syvårskrigen melde afbud til brylluppet, men sendte til gengxld ca. 7.500 liter vin til festen.

Tre år efter døde enkedronningen. Hans den Yngre, som havde været tæt knyttet til moderen, følte, at han havde mistet sin mest trofaste ven i verden. 


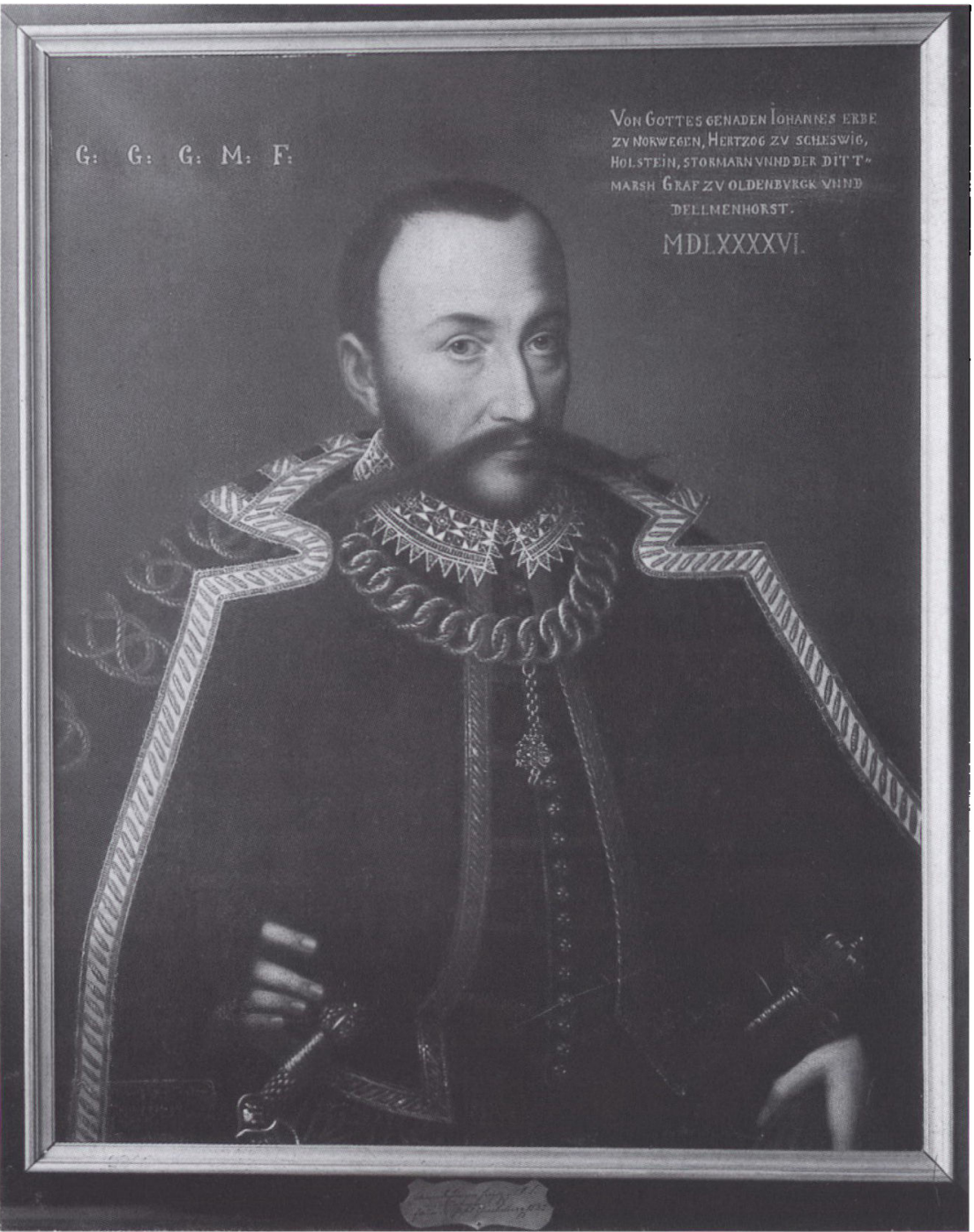

Hans den Yngre (1545-1622). Pd grund af sin lutherske selvforstålse havde han behov for, at kirkehojheden fulgte landshojheden. Behovet var så starkt, at sporgsmalet var aktuelt for hertugen fra enkedronningens dod $i 1571$ til hans egen dod i oktober 1622. Foto efter maleri 1596 pa Glücksborg slot.

I Dorotheas testamente fra 1569 var Hans den Yngre nærmest gjort til universalarving, og det var Frederik II naturligvis utilfreds med. Reelt set blev det Hans den Yngre, som overtog hele arven, idet kongens gæld til moderen udlignedes i forbindelse med arvedelingen. 
Hans den Yngre fik 14 børn med Elizabeth. De mange graviditeter tog imidlertid på hendes i forvejen sarte helbred, og hun døde allerede den 12. februar 1586. Dagen før var svogeren, kurfyrst August af Sachsen død. Han efterlod sig den knap 13-årige enke, Agnes Hedvig (født 12/3-1573). Hans den Yngre tog ned for at besøge den unge enke, og 5 . november 1587 blev der indgået ægteskabskontrakt. Medgiften var på ikke mindre end 30.000 rigsdaler, hvoraf kun 15.000 kunne arves. Den anden halvdel skulle til sin tid tilbagebetales. Hans den Yngre havde økonomisk set gjort et godt parti. Brylluppet fandt sted 14. februar 1588 på Sønderborg Slot, og denne gang havde Frederik II mulighed for at deltage.

Egteskabet blev godt, men Agnes Hedvig var ligesom Elizabeth svagelig. $\mathrm{Ni}$ fødsler og mindst én abort gjorde det ikke bedre. Da hun døde 3 . november 1616, havde hun i mere end seks år været plaget af tuberkulose.

Hans den Yngre rejste en del rundt i sine besiddelser, men boede fortrinsvis på Sønderborg Slot. Han blev efterhånden en velstående mand, hvilket især må tilskrives hans veldrevne landbrug. Han sagde selv, at hans alkymi lå $\mathrm{i}$ et praktisk landbrug. Hertugen døde den 9. oktober 1622 på Glücksborg Slot og blev i slutningen af november bisat i Sønderborg Slotskirke. ${ }^{12}$

Hans den Yngre kæmpede i talrige år, for at blive anerkendt af stænderne som suveræn fyrste. Gang på gang tog han - forgæves - spørgsmålet op. Kongen søgte at ligestille ham med de øvrige hertuger, men stænderne nægtede alligevel at hylde ham. Hans den Yngre måtte derfor affinde sig med en rolle som »afdelt herre«. Anerkendelse som regerende fyrste fik han aldrig. Den lange - men resultatløse - kamp for en stænderhyldning var først og fremmest begrundet $\mathrm{i}$ hertugens stærke ønske om at få anerkendelse som fyrste med fyrstelig jurisdiktion samt de økonomiske fordele, der fulgte heraf. Hans den Yngre opfattede sig selv som en selvstændig landsherre, der havde krav på uindskrænket regeringsmagt. ${ }^{13}$ Forbilledet så han i reformationstidens tyske territorialfyrstendømmer.

Fyrsteidealet i disse territorialfyrstendømmer er beskrevet af Fritz Hartung $i$ en artikel fra 1912. I store stater var magtpolitikken det helt afgørende. I de små fyrstendømmer spillede religionen - $\mathrm{i}$ forlængelse af det lutherske fyrstekirkeideal, hvor kirkehøjhed fulgte landshøjhed - en næsten lige så vigtig rolle. Territorialfyrsterne så deres styre som et af Gud overdraget hverv. Hartungs konklusion er imidlertid, at territorialfyrstendømmet i virkeligheden ikke kan betegnes som en stat, men derimod var en mellemting mellem en stat og et stort gods. ${ }^{14}$

E. Ladewig Petersen har $\mathrm{i}$ sin anmeldelse af Jørgen Steen Jensens biografi om Hans den Yngre stærkt understreget hertug Hans den Yngres territorialfyrstelige selvforståelse. Ladewig Petersen fremhæver hertugens lange kamp 
for at få stændernes hyldning og hans tyskorienterede ægteskabspolitik som klare træk i denne retning. Om Hans den Yngres administration hedder det: »Hertug Hans' forvaltning og hans jurisdiktionskrav præges som Jørgen Steen Jensen fremhæver af krav på ubetinget autoritet. Hans administration varetages efter tyske territorialfyrstelige mønstre af borgerlige og lærde embedsmænd og fra slutningen af 1500-tallet også af uadelige fogeder på lokalt plan ... På den anden side må den - konfessionelt begrundede - fordring på ubetinget øvrighedsmyndighed som forfatteren flere gange nævner utvivlsomt forbindes med fyrstemagtens utrættelige og ofte smålige anstrengelser for at sikre sine finansielle ressourcer og absolutte uafhængighed, et træk der påny røber hertug Hans' dybe forankring i tysk territorialfyrstelig tradition ${ }^{15}$

Som en yderligere understregning af Hans den Yngres profilering som uafhængig fyrste kan tillige nævnes hans møntvæsen. Møntprægningen havde sin formelle baggrund i det lensbrev han fik på Holsten af kejser Rudolf II i 1590. Møntproduktionen var af marginal betydning, men prestigemomentet har set $\mathrm{i}$ lyset af det ovenstående - nok også været det afgørende for hertugen. ${ }^{16}$

Endelig var der spørgsmålet om kirkehøjheden. Den indgik også i Dorotheas og Hans den Yngres bestræbelser for at opnå den fulde øvrighed i deres besiddelser. Dét er emnet i det nedenstående.

\section{Tiden 1566 til 1571}

\section{Enkedronning Dorotheas provst på Als og Sundeved}

Den 12. juni 1566 udnæunte enkedronning Dorothea pastor Johann Berndes af Broager til sin egen - af Odense Stift uafhængige - provst over Als og Sundeved. Den hidtidige provst på Als siden 1563, Jørgen Thomsen (Georg Thomæ) fra Egen sogn, måtte derfor afgive sit provsti. ${ }^{17}$

Det ville Frederik II imidlertid ikke acceptere, da det var en krænkelse af Danmarks riges hojhed og rettighed. Desuden ville det betyde, at Hans den Yngre sidenhen ville kræve kirkehøjheden, når han efter moderens død skulle overtage området. ${ }^{18}$

Enkedronningen forsvarede sig i brev af 23. marts 1567 med, at hun havde udnævnt en ny provst på Als og Sundeved af gode, kristelige årsager, da den tidligere provst var gammel, syg og tilmed ulærd. Desuden havde han bedt om at få lov til at trække sig tilbage. Enhver vidste, at kirkerne var blevet styret dårligt $i$ hans embedstid. Den nye provst var til gengæld en vellidt mand $i$ sin menighed og prædikede den rene lære. Med hensyn til Ærø var kongens kritik helt uberettiget: enkedronningen havde nemlig ikke indsat nogen provst på Ærø. Dorothea bemærkede desuden, at når hun døde skulle Hans den Yngre 
arve Sønderborg Amt med al højhed og rettighed. Det var derfor ikke urimeligt til sin tid at indrømme hertugen den kirkelige jurisdiktion, for han havde vel ikke mindre ret til denne end hertug Adolf, der ved starten af sin regering straks overtog jurisdiktionen over de af sin landsdels kirker, som indtil da havde hørt under Ribe Stift. ${ }^{19}$

Hvad der øjensynligt bekymrede kongen mest var, at Hans den Yngre sidenhen også ville kræve den kirkelige jurisdiktion, hvis den blev indrømmet enkedronningen. Hen på sommeren bad kongen derfor igen sin moder om at opgive sine krav om begunstigelser på kirkeområdet, eftersom hele sagen kun ville føre til splid og uenighed mellem Frederik II og Hans den Yngre, når enkedronningen var død. ${ }^{20}$ Dorothea var imidlertid ikke til sinds at skifte standpunkt og tilføjede, at den fynske biskop ${ }^{21}$ med årene var blevet syg og kun sjældent visiterede kirkerne, som derfor med tiden var blevet stærkt forsømt. Som stedets øvrighed havde Dorothea ikke set anden mulighed, end at hun måtte gribe ind. Alt var sket af kristelig velvilje og aldeles ikke for at skabe uenighed mellem kongen og hans broder.

Trods denne »kristelige« begrundelse kan der næppe være tvivl om, at enkedronningens virkelige motiv var et stærkt onske om at indehave både den verdslige og gejstlige højhed. Dorothea fremdrog nemlig påny eksemplet med hertug Adolf, som havde fået kirkehøjheden over nogle kirker i sin landsdel, som tidligere var styret af biskoppen i Ribe. Det forekom Dorothea, at Hans den Ældre havde gjort det tilsvarende med Femern. Derfor skulle noget lignende ikke give anledning til fjendskab mellem moder og søn, men derimod udløse en accept af den nye provst. ${ }^{22}$

Dorothea havde tydeligvis ikke for ingenting varet med til reformationen af kirken og oplevet det lutherske fyrstekirkeprincips virkeliggørelse i Haderslev Amt og Tørning Len i 1528. Som indehaver af landshøjheden kunne hun ikke acceptere at være sat ud af spillet, når det angik kirkehøjheden. De to elementer hang nøje sammen i det landsfyrstelige kirkeregimente, hvor den overordnede magt lå hos den territoriale, verdslige øvrighed. ${ }^{23}$

\section{Frederik IIs modtrak}

I midten af august 1567 fandt Frederik II det nødvendigt at sende de to rigsråder Jørgen Lykke og Jørgen Rosenkrantz til Als og Arø for at undersøge den gejstlige jurisdiktionsstrid nærmere. Samtidig skulle de også varetage kronens rettigheder over noget kirke-gods og -tiende ${ }^{24}$ på øerne, som under Christian III for en tid var lagt til Sønderborg Amt, men ikke som ejendom. Det drejede sig om pantegods, der havde hørt under Sankt Knuds Kloster i Odense, og som enkedronningen tidligere havde indløst hos den nu afdøde Johann Reventlow samt gods opnået ved mageskifter. Desuden havde Sønderborg modtaget 
tiendeindtægter fra krongods på Als og Ærø. Ved arvedelingen med Hans den Yngre i 1564 havde kongen forbeholdt sig dette gods, men ønskede ikke desto mindre at overtage godset nu, så det ikke gav anledning til problemer i forholdet til Hans den Yngre, når enkedronningen en dag døde. ${ }^{25}$

Kongen ville altså én gang for alle fastslå Danmarks ret til kirkehøjheden på Als og Ærø. Ærø hørte ganske vist til Dorotheas livgeding, men hun havde ret beset ikke indsat nogen provst dér. Men hvis provsteudnævnelsen på Als og Sundeved var gået mere smertefrit end tilfældet blev, så ville enkedronningen utvivlsomt have taget Ærø med under den nye provsts tilsyn eller udnævnt endnu en provst, eftersom både Als og $Æ$ rø hørte under den fynske biskop.

Frederik II fokuserede meget på det fremtidige forhold til Hans den Yngre, og det var derfor meget naturligt, at han ville have afklaret spørgsmålet om den gejstlige jurisdiktion på begge øer på én gang, da hertugen skulle arve dem begge.

Rigsråderne skulle også varetage kronens interesser med hensyn til kirkegodset, men hvorfor? Kongen havde jo allerede i arvedelingen fra 1564 forbeholdt sig godset ved en fremtidig deling af moderens arv? Var det en undskyldning for at overtage godset og indtagterne derfra allerede nu? Det virker imidlertid mere sandsynligt, at kirkegodset skulle bruges til at lægge økonomisk pres på moderen, for at få hende til at opgive sine planer om egen gejstlig jurisdiktion.

Den 14. august 1567 fik bønderne og den menige almue på Als og Erø i åbent brev påbudt at lyde den mand, som Lykke og Rosenkrantz måtte udnævne til at varetage kronens interesser med hensyn til kirkegodset. Provster, præster og degne fik $\mathrm{i}$ åbent brev henstilling om at rette sig efter den fynske biskop og $\mathrm{i}$ dennes fravær den provst, som de to råder måtte udnævne til embedet. Selv om der $\mathrm{i}$ den seneste tid havde været nogle forhindringer, så havde den fynske biskop altid haft den gejstlige jurisdiktion på de to øer og ville fortsat have den. ${ }^{26}$

Enkedronningen fik også et brev, hvori kongen understregede det nytteløse $i$, at Dorothea gang på gang fremdrog hertugerne Adolf og Hans den Eldre som lignende eksempler. Det var fejltagelser, som ikke skulle give anledning til sammenligninger med deraf følgende krav på kongens og rigets nedarvede rettigheder. ${ }^{27}$

\section{Jorgen Lykkes og Jorgen Rosenkrantz' rejse}

Den 24. august 1567 ankom Jørgen Lykke og Jørgen Rosenkrantz til Kolding. Med sig havde de Balthasar Liebenthall, som nedskrev hele rejsens forløb. På Koldinghus blev de modtaget af enkedronning Dorothea. Hertug Hans den Yngre var også til stede. Enkedronningen udtrykte sin forbløffelse over kon- 
gens reaktion på hendes provsteudnævnelse. Hun kunne ikke se, at det i hendes levetid skulle kunne give mindste årsag til uenighed mellem hendes børn. Dorothea håbede, at kongen ville skåne hende for den spot, der nemt kunne opstå hos den almindelige mand på grund af provstesagen, og derfor lade den nye provst blive i embedet.

Enkedronningen var villig til at afgive det oprindeligt kirkelige pantegods på Als og Ærø, hvis hun fik de penge igen som hun havde lagt ud og kunne fă indtægterne af godset for indeværende år. Hvad det var for noget gods, som var lagt til Sønderborg, men tilhørte Fyns Stift og stammede fra mageskifter med adelen, kunne Dorothea til gengæld ikke erindre.

De to rigsråder havde fået kongelig befaling om at udnævne en ny provst og kunne derfor ikke godkende Johann Berndes. Med hensyn til pantet, så tilbød Lykke og Rosenkrantz at betale beløbet, som var på 1.800 daler. Dorothea accepterede at modtage pantesummen og til gengæld aflevere hovedbrevet på godset, men det måtte vente nogle dage, da brevet befandt sig på Sønderborg Slot. ${ }^{28}$

Dorothea fastholdt hårdnakket, at hun havde udnævnt sin egen provst af kristelige årsager, men det virker ikke overbevisende. Dorothea spurgte ingen, før hun foretog sit indgreb - vel vidende, at hun aldrig havde haft ret til at styre kirkerne på øerne. Bagefter appellerede hun til Frederik IIs samvittighed og medlidenhed ved at fremhæve den folkesnak, som ville opstå, hvis den nye provst blev afsat. Dorothea påstod nærmest, at kongen gjorde hende fortræd i hendes enkestand, hvis han krævede kirkehøjheden på øerne tilbage. Der ligger utvivlsomt taktik bag sådanne udtalelser, for kongen ville vel ikke give anledning til sin moders latterliggørelse?

Tør man tro rigsrådernes beretning, så tilkendegav enkedronningen åbenlyst sin frygt for en forringelse af Hans den Yngres fremtidige fyrstelige rettigheder i forhold til de to hertugelige farbrødre, når han efter enkedronningens død skulle overtage områderne. Derved bliver spørgsmålet om kirkehøjheden det centrale, medens de kristelige motiver reduceres til dårlige undskyldninger.

Efter mødet med enkedronningen tog Jørgen Lykke og Jørgen Rosenkrantz videre til Als. I den afsatte provst Jørgen Thomsens bolig havde den fynske biskop, Niels Jesperssøn, efter aftale med rigsråderne indfundet sig sammen med hele øens gejstlighed. Lykke og Rosenkrantz havde også bedt bønderne fra Lysabild og andre områder, som hørte under Fyns Stift, om at komme derhen.

Man startede med forhandling med gejstligheden, og kongens åbne brev blev læst op. Herefter skulle præstestanden tage en beslutning og gik derfor ud $i$ haven for at tale sammen. Mens de var dér, kom enkedronningens amtsskriver på Sønderborg i amtmandens fravær og erindrede dem om deres højti- 
delige løfte til enkedronningen. Derfor skulle de hver især gå hjem og ikke adlyde de kongelige råder.

Amtsskriveren meddelte rigsråderne, at deres instruks ikke alene var imod enkedronningens vilje, men også var en fremtidig fratagelse af enkedronningens og Hans den Yngres velerhvervede rettigheder over området. Rigsråderne ville imidlertid ikke lade sig opholde af hans protester mod deres kongeligt pålagte opgave og fandt det ganske unødvendigt at gå ind i en diskussion.

Herefter tog råderne videre til Ærø, hvor de - ligesom på Als - mødtes med præsterne. Disse havde alle modtaget en skrivelse fra amtsskriveren i Sønderborg, som ville forhindre mødet med den lokale gejstlighed og rigsråderne; men det havde øjensynligt intet nyttet.

Efter mødet på ÆErø tog rigsråderne hjem til deres respektive godser. Biskoppen tog derimod først til Sønderborg, eftersom Dorothea havde bedt ham om, inden han tog tilbage til Fyn, at komme til Sønderborg sammen med den gamle provst, for at de kunne tale om provsteanliggendet. ${ }^{29}$

Sådan som rigsrådernes rejse præsenteres $i$ den samtidige beretning er det let at skelne sort fra hvidt. Det må imidlertid ikke glemmes, at beretningen er skrevet af rigsrådernes ledsager, Balthasar Liebenthall, som utvivlsomt havde valgt side i striden.

Enkedronningen gik klart over stregen ved at hævde sin ret til at styre kirkerne på Als og Ærø. I forbindelse med provstestriden kan det ikke undre, at enkedronningen ønskede den alsiske gejstligheds lydighed, men det virker til gengæld uklogt, at hun også sendte skrivelser til de ærøske præster, hvor hun ingen stridigheder havde haft hidindtil. Herved udstrakte hun nemlig selv ligesom Frederik II allerede havde gjort det - striden til at omfatte begge øer. Dorothea krævede, at præsterne var lydige overfor hende $i$ hendes egenskab af områdets verdslige øvrighed, medens kongen holdt på Odense Stifts gamle nedarvede rettigheder.

\section{Dorothea lagger kursen om}

Den 5. september 1567 skrev enkedronning Dorothea påny et brev til Frederik II angående kirkestriden. Enkedronningen fandt, at Jørgen Lykke og Jørgen Rosenkrantz havde handlet overilet. Hendes provsteudnævnelse var jo ikke tænkt som en næsvished eller ond handling. Provst Thomsen havde imidlertid en fortid som glarmestersvend, og det var dét, der - sammen med hans manglende lederevner - gjorde ham uskikket til provsteembedet. Biskoppens manglende visitatsrejser blev forklaret med, at han havde for meget arbejde. Derfor havde Dorothea taget initiativ til at aflaste ham ved at indsætte en fornuftig mand som provst. Iøvrigt mente enkedronningen, at var hun gået for langt, så var hun dog moderen og kongen sønnen! 
Dorothea fremhavede, at alle præsterne på Als samstemmende havde bekendt, at de havde måttet svigte deres forpligtelser overfor enkedronningen, fordi Jørgen Lykke truede dem med halshugning. Problemet var iøvrigt ikke særlig stort: enkedronningen havde jo ikke så lang levetid tilbage, at hendes styring af kirkehøjheden kunne nå at blive til en tradition inden Hans den Yngre skulle træde til. Provsteindsættelsen skulle altså ikke længere sammenlignes med hertugerne Adolfs og Hans den Aldres jurisdiktionsrettigheder i deres landsdele, men blot være en undtagelse fra reglen! Hans den Yngre skulle ikke have nogen kirkehøjhed til sin tid.

Kort sagt havde enkedronningen - belært som hun trods alt var blevet af kongen og råderne - indskrænket sit tidligere krav om den fulde kirkehøjhed på øerne til kun at være en særlig ordning, som undtagelsesvis skulle indrømmes hende! $!^{30}$

\section{Et kompromis}

Selv om der kom nye toner fra enkedronningen, ville hun dog ikke give sig, når det gjaldt den nye provst; men kong Frederik II havde heller ikke tænkt sig at give efter. Omdømmet var nemlig vigtigt, hvis han skulle få de ulydige bønder til at vise lydighed. Til gengæld var kongen villig til at overlade enkedronningen det gods på Als og Ærø, der tilhørte kongeriget og som var udeladt $i$ arvedelingen. Hun kunne få det på livstid, hvis hun med hånd og segl lovede, at Hans den Yngre ikke skulle have noget af dette gods, når hun døde. Kongen ville beholde den gejstlige jurisdiktion og bad derfor moderen om - uden nogle forhalingsmanøvrer - at give afkald på sin begunstigelse. ${ }^{31}$ I et skarpt brev af 18 . september forsvarede Frederik II Jørgen Lykkes optræden. Gods, som fra gammel tid havde hørt til Sønderborg Amt, ville kongen gerne overlade sin moder; men gods, der tilhørte Sankt Jørgens hospitalet ved Svendborg ville kongen ikke overlade hende. Biskoppen måtte desuden ikke hindres i visitation og anden virksomhed i området, som fra gammel tid tilkom bispeembedet. ${ }^{32}$

Dorothea blev glad for, at kongen ville give hende bønderne på Ærø, men bad tillige om, at det reventlowske pantegods måtte komme hende $\mathrm{i}$ hænde igen. Ønsket fulgtes af en forsikring om, at hvad man gjorde for at ære sin moder, ville blive rigeligt belønnet af Gud. ${ }^{33}$ Opfordringen blev gentaget tre dage senere i et nyt brev til kongen og igen i slutningen af oktober, da enkedronningen meddelte kongen, at Hans den Yngre og Elizabeth havde "fattet kærlighed til hinanden « og ville indgå ægteskab. ${ }^{34}$

Frederik II svarede i et venligt brev, at når pantegodset og det andet gods, som skiftevis havde været lagt under kongeriget og Sønderborg Amt, var blevet taget tilbage af kongen, så var det alene for at undgå fremtidig broderlig uenighed om godset. Derfor var det også nødvendigt med en specifikation over 


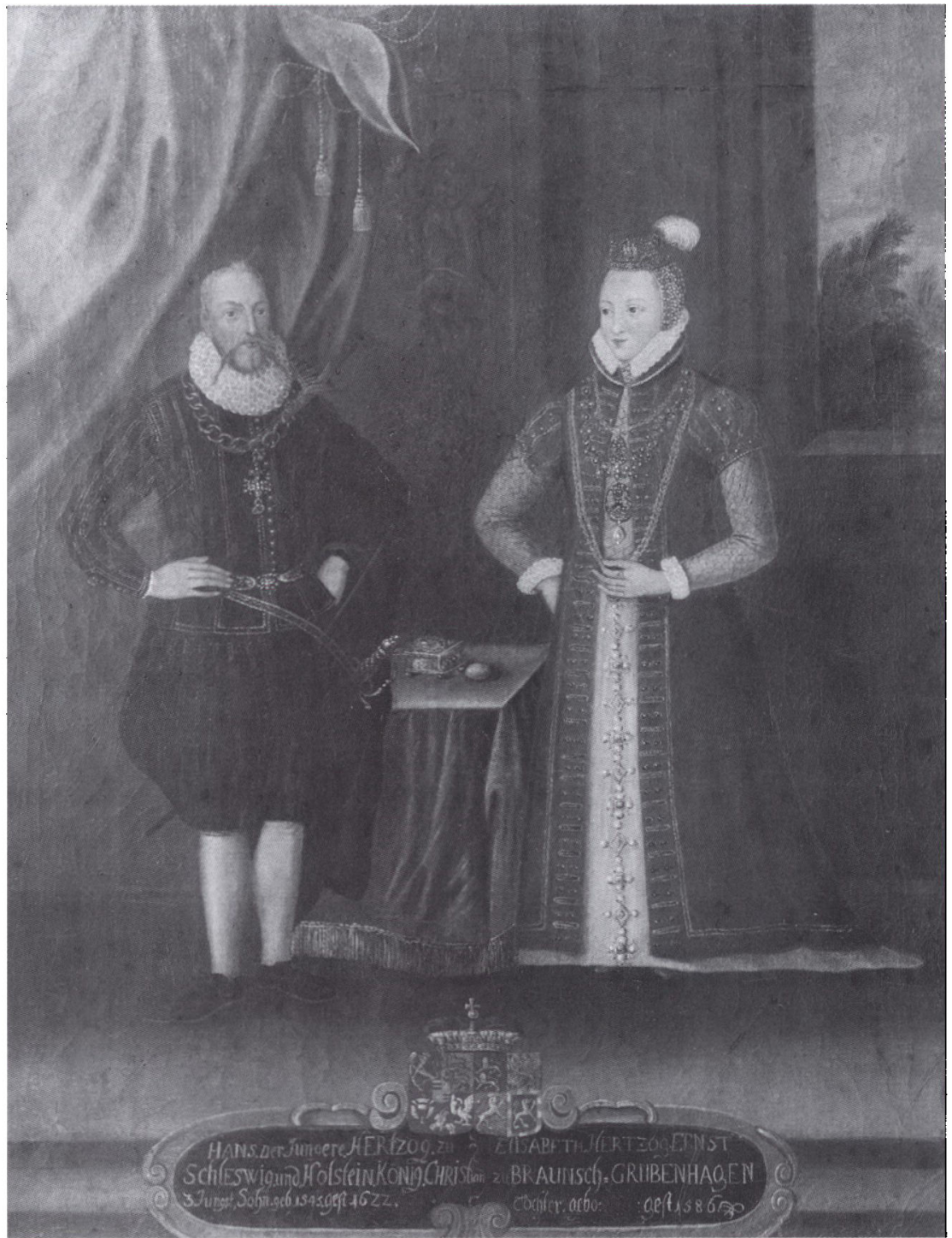

Hertug Hans den Yngre med sin forste gemalinde, Elisabeth af Braunschweig-Grubenhagen. De blev viet i 1568. Hun dode 1586. Foto i Museet pd Sonderborg Slot.

godset. $\mathrm{Nu}$ hvor enkedronningen havde anerkendt arvedelingsbrevene, var kongen tilfreds og sendte derfor sin moders skøder på godset retur. Panteskillingen på 1.800 daler måtte Dorothea også beholde, men kongen ønskede en kvittering på den og bad om at få pantegodsskøderne tilsendt. ${ }^{35}$ 
Brevet faldt - som man kunne vente - $\mathrm{i}$ god jord hos enkedronningen. Hun takkede den 30. oktober 1567 for overdragelsen af de ærøske bønder og vedlagde de af kongen ønskede skøder på pantegods samt en kvittering på pantesummen.

Om provstesagen fastholdt Dorothea, at hun havde ladet sig lede af Gud. Hun ønskede ikke at fratage riget eller kongen nogen rettighed. Tværtimod bad enkedronningen om, at Frederik II til ære for hende påny lod Johann Berndes blive indsat som provst, men denne gang af den fynske biskop og $\mathrm{i}$ kongens navn. ${ }^{36}$

Kongen svarede $\mathrm{i}$ begyndelsen af november, at han nu havde givet amtmand Gadendorff besked om, at de ærøske bønder igen var gået tilbage til enkedronningen. Borgmesteren $\mathrm{i}$ Kolding, som tidligere havde modtaget pantesummen, havde fået besked om, uden tøven, at give den til enkedronningen. Væsentligst var det imidlertid, at Frederik II var blevet klar over, at provsteudnævnelsen ikke var foretaget for at forringe kongens eller rigets rettigheder, men derimod var gjort $\mathrm{i}$ kristelig iver for at befordre det saliggørende ord. Derfor ville han nu lade Johann Berndes indsætte som provst af den fynske biskop! ${ }^{37}$

Fra da af ophørte korrespondancen i jurisdiktionsstriden mellem kongen og hans moder. Johann Berndes blev provst på Als og Sundeved - valgt af enkedronningen, men udnævnt af kongen.

Spørgsmålet bliver da: fik enkedronningen noget ud af sin lange brevveksling med Frederik II i 1567? Svaret afhænger af synsvinklen. Udadtil havde enkedronningens anliggende jo hele tiden været at få udskiftet provst Jørgen Thomsen og få indsat sin egen. Det lykkedes for hende. Det virker imidlertid ikke troværdigt, at enkedronningens eneste mål var at få udskiftet en provst. Begrundelsen svækkes af hendes handlemåde. Langt mere sandsynligt er det derfor, at enkedronningen ville sikre sig kirkehøjheden, for at Hans den Yngre senere kunne overtage sit hertugdømme med fuld lands- og kirkehøjhed. Muligvis havde hun håbet, at kongen ville være eftergivende, da han $\mathrm{i}$ disse år havde langt større problemer at håndtere i forbindelse med Den nordiske Syvårskrig. Men det var kongen ikke.

Det helt afgørende for Frederik II var, at kirkehøjheden fortsat var kongens. Det var vigtigt at fastholde, hvis en fremtidig uenighed om den gejstlige jurisdiktion skulle undgås mellem Hans den Yngre og Frederik II. Ved at inddrage det tidligere kirkegods på Als og Ærø havde kongen ramt sin moder på pengepungen. Taktikken virkede: Dorothea opgav sit krav på kirkehøjheden og fik alt sit gods igen, medens Frederik II fik understreget, at den gejstlige jurisdiktion over Als og Ærø alene tilhørte kongen. 


\section{Tiden 1571 til 1579}

Frederik II genopretter den gamle orden

Kun et par uger efter enkedronningens død den 7 . oktober 1571, udsendte Frederik II nye befalinger angående Als og Ærø i kirkelig henseende. Den kongelige overhøjhed skulle fastslås i sin fulde udstrækning.

Bønderne på Als og Ærø fik besked om at være embedsmanden på Nyborg, Axel Viffert, lydige. Viffert skulle oppebære kronens part af tienden med herligheden af alle kirker, kirkegods og præstegæsteri på øerne. Det tilhørte altsammen Fyns Stift, men havde med Christian IIIs tilladelse været brugt af Sønderborg Slot, dog ikke som ejendom. Provster, sognepræster og degne på øerne fik besked om, at de fynske biskopper altid havde haft den gejstlige jurisdiktion på Als og Erø. Derfor skulle gejstligheden på øerne være lydige mod embedsindehaveren og $i$ hans fravær den af ham indsatte provst.

Biskoppen fik besked om at rejse til Als og Erø sammen med Axel Viffert, for at få orden på den gejstlige jurisdiktion og kirketugten. Biskoppen skulle byde præsterne at følge kirkeordinansen og visitere årligt samt $i$ sit fravær indsætte en provst til at føre tilsyn med de gejstlige sager. Kongen bemærkede i befalingen til biskop Niels Jesperssøn, at enkedronningen med kongens tilladelse havde brugt den gejstlige jurisdiktion på Als og Erø i sin levetid. ${ }^{38}$

Kilderne melder i 1567 intet om, at Berndes eller nogen anden blev provst på Ærø, men de kongelige befalinger fra oktober 1571 lader $i$ hvert fald ingen tvivl tilbage om, at brugen af Odense Stifts gejstlige jurisdiktion har været overladt til enkedronningen på begge øer. ${ }^{39}$

Resultatet af Vifferts og Jesperssøns rejse blev, at Jørgen Thomsen blev genindsat som provst på Als, hvor han blev til sin død i $1581,{ }^{40}$ medens Johann Berndes måtte nøjes med Sundeved som sit provsti. ${ }^{41}$ Ved samme lejlighed blev der lavet et register over de bønder, som skulle svare lensafgifter til Axel Viffert på Nyborg Slot. ${ }^{42}$

Kongen skrev også til Hans den Yngre og erklærede, at amtmanden på Nyborg skulle tage vare på det gods på Als og Ærø, som tilhørte kronen, men havde været lagt til Sønderborg. Kongen understregede, at det skete ifølge en klar aftale, hvori også indgik, at den gejstlige jurisdiktion på øerne fuldt ud var kongens. ${ }^{43}$ Frederik II stod fast, men havde trods alt forståelse for Hans den Yngres utilfredshed hermed. ${ }^{44}$

\section{Hans den Yngre genoptager kirkestriden}

Den 24. april 1572 skrev hertug Hans den Yngre til Frederik II og takkede for den tilsendte fortegnelse over det gods på Als og Ærø, som embedsmanden på Nyborg havde overtaget forpligtelserne på. Hertugen understregede, at han 
i sandhed(!) ingen anelse havde haft om, at enkedronningen havde haft gods på øerne som pant. Hans den Yngre vidste ikke bedre, end at han skulle overtage Sønderborg Amt med al højhed, herlighed og øvrigt tilhørende. Han havde aldrig hørt, at der lå dansk gods på Als, og med hensyn til den gejstlige højhed, så var denne ikke udtrykkeligt udeladt i arvedelingsaftalen. Desuden udøvede hertugerne i Holsten uhindret den kirkelige højhed i deres arvede lande. ${ }^{45}$

Hans den Yngre begrundede sin fordring på kirkehøjheden med, at han skulle have sit fyrstelige underhold fra huset Sønderborg, men uden højheden ville det være vanskeligt for ham at varetage sin stilling. Spørgsmålet bliver derfor, om kirkehøjheden skulle legitimere hertugens krav på det sekularisede kirkegods? Skulle kirkehøjheden over øerne give Hans den Yngre større myndighed over undersåtterne? Eller bad Hans den Yngre om at måtte råde over den kirkelige højhed over Als og Frø i lighed med de holstenske fyrster, fordi han sammenlignede sig med de tyske territorialfyrster, som hver især var kirkeherrer $\mathrm{i}$ deres respektive fyrstendømmer?

I løbet af de næste måneder fortsatte Hans den Yngres opfordringer til kongen om at afgive kirkehøjheden og det sekulariserede kirkegods. Særligt påfaldende er hertugens brev af 13. november 1572, hvor han fremførte, at bønderne forsøgte at blive underlagt embedsmanden på Nyborg for at slippe for at yde hoveri. Fortsatte tendensen, ville hertugen tilsidst ikke have en eneste bonde tilbage. Siden moderens død havde hertugen mødt en sådan ulydighed og uvilje blandt folk, at han ikke havde været glad en eneste dag! Hans den Yngre ville ikke give anledning til kongens vrede, men kunne på den anden side ikke undlade at bede om dennes hjælp, da tingenes tilstand giorde, at han hellere ville være død end levende. ${ }^{46}$

Efter at have læst dette triste brev, svarede Frederik II, at han hverken kunne eller ville afgive kronens eller Fyns Stifts gods på Als og Ærø; men han var da ked af, hvis hertugens bønder var så ulydige, som det var fremstillet i brevet. ${ }^{47}$

Det er svært for en sen eftertid at bedømme realiteterne bag disse breves udsagn. Hans den Yngre havde tilsyneladende et alvorligt autoritetsproblem, men det er ikke svært at finde et motiv, som kunne begrunde en overdrivelse: det lyser næsten ud af brevet, at problemerne ville løse sig i det øjeblik kongen afgav sit gods i området. Frederik II så naturligvis straks denne sammenhæng, og det kan måske forklare den fasthed han endnu en gang fremviste. Frederik II var urokkelig.

Selv om hertugens brev på denne måde kan reduceres til en simpel overdrivelse, er det alligevel tvivlsomt, om det nu også alene var med godsforøgelse for øje, at brevet blev skrevet. Hertugens meget stærke vendinger virker næsten for kraftige, hvis det bare var for at opnå en godsforøgelse. Efter enkedronnin- 
gens håndfaste styring af enkegodset - hvori også indgik det fynske kirkegods - er det egentlig heller ikke svært at forestille sig den autoritative svækkelse som den unge uerfarne hertug oplevede ved, at der pludselig var hertugelige bønder og kongelige bønder i det samme lille område. Hertugens indflydelse var blevet synligt formindsket i forhold til moderens. Endelig er det indlysende, at bønderne forsøgte at blive registreret som kongelige bønder. Derved kunne de nemlig nøjes med at betale skat til deres fjerne herre, medens de under hertugen var nødt til at yde hoveri. ${ }^{48}$

\section{Forhandlinger $i$ årene 1573-1574}

I april 1573 mødtes Hans den Yngre med Frederik II på Dronningborg Slot ved Randers for at diskutere jurisdiktionsstriden. ${ }^{49}$ Hertugen brugte på den ene side et økonomisk argument for at retfærdiggøre sit krav på krongodset på Als og Ærø: han havde brug for store indtægter til sin fyrstelige husholdning. Og på den anden side et autoritetsargument: bønderne flygtede fra det hertugelige gods til krongodset.$^{50}$ Argumenterne var tæt indbyrdes forbundne, idet indtægterne afhang af godsdriften, som igen afhang af bønderne. Det vigtigste anliggende var dog ikke at få krongodset overdraget for godsforøgelsens skyld, men for at få større autoritet, idet kongens gods indenfor Hans den Yngres hertugdømme svækkede hertugens autoritet og myndighed.

Hertugens krav på den gejstlige jurisdiktion på Als og Ærø begrundedes i, at selv adelen brugte den gejstlige jurisdiktion i hertugdømmet Slesvig. Tidligere havde Hans den Yngre ligefrem spurgt Frederik II om adelen havde bedre betingelser end hertugen - som dog var kongesøn - siden den kunne få kirkehøjheden overdraget. ${ }^{51}$ Et umuligt spørgsmål, da Als og Ærø jo var en del af Odense Stift med deraf følgende dansk lovgivning. Hans den Yngre følte sig kort sagt stækket på to områder: eksistensen af kongeligt gods i det lille hertugdømme og den manglende kirkehøjhed. Overordnet handlede det altså om autoritet og myndighed - både som hertug og som godsejer, da det jo var to sider af samme sag.

Kongen fastholdt imidlertid sit standpunkt. Eneste resultat af forhandlingerne var en aftale om et nyt møde i juni i Kolding, som også viste sig frugtesløst. ${ }^{52}$ Frederik II ønskede beviser for Hans den Yngres krav, hvilket - i modsætning til kongens statslige dokumenter og jordebøger - ikke lod sig gøre. ${ }^{53}$

I efteråret 1573 indvilligede kongen i at lade kurfyrst August af Sachsen og hertug Ulrik af Mecklenburg deltage i nye forhandlinger om striden. ${ }^{54}$ Mødet fandt sted i slutningen af marts 1574 i Odense. Til stede var foruden Hans den Yngre, svogeren kurfyrst August, hertug Ulrik og en række råder fra de berørte områder.

I håbet om at kunne afhjælpe den broderlige strid havde kurfyrst August 
og hertug Ulrik lavet et mæglingsforslag, som blev forelagt parterne. Kongen skulle beholde den gejstlige jurisdiktion over Ærø fuldt og helt via den fynske biskop. Hans den Yngre skulle til gengæld have kirkehøjheden over Als. Godsspørgsmålet skulle løses ved, at kongen på Ærø beholdt de 25 tidligere reventlowske bønder og de 10, som stammede fra et mageskifte med Jacob Brockenhus. De stridbare bønder, som mæglerne havde hørt om, skulle deles i to halvdele: én til kongen og én til hertugen - begge dele som ejendom. Hermed skulle problemerne ifølge mæglerne kunne afhjælpes.

Hans den Yngre gik ind for forslaget. De kongelige råder kunne imidlertid kun tage forslaget til efterretning, da deres instruks ikke gav dem retningslinier på dette punkt. Kongen skulle - inden for fire måneder - være frit stillet til at sige ja eller nej til forslaget. Hvis kongen accepterede forslaget, skulle Hans den Yngre erklære sig tilfredsstillet og ikke fremtidigt kræve noget af kongens andel, såvel som kongen heller ikke kunne kræve ændringer. Hvis kongen derimod forkastede forslaget, så skulle forholdene være som før, uden nogen fratagelse af tidligere rettigheder. ${ }^{55}$

Synspunkterne ved Odense-forhandlingerne var velkendte, omend det denne gang blev tydeligere præciseret end tidligere, at Hans den Yngres krav på bønderne på Als og Ærø ikke var berettiget. Til gengæld fik hertugen gjort klart rede for sin territorialfyrstelige selvopfattelse ved at fremhæue, at pavens afgang som kirkeherre i de lutherske områder gjorde de respektive landsherrer til kirkeherrer. Kirkehøjheden skulle følge landshøjheden.

Mæglingsforslaget var et udpræget kompromis, der principielt set hverken gav kongen eller hertugen ret i deres opfattelser. Set fra kongens side var kirkehøjheden jo både på Als og Ærø ubetinget kongelig ejendom via Odense Stift, men mæglerne foreslog kirkehøjheden delt $\mathrm{i}$ to, hvorved kongens højhedsret blev tilsidesat på Als, hvor Hans den Yngre skulle være kirkeherre. Hans den Yngre var imidlertid hertug både på Als og Ærø, og dermed var der heller ikke sket nogen anerkendelse af dennes krav om fuld kirkehøjhed.

Godsspørgsmålets løsningsforslag var ligeledes et kompromis. På grundlag af arvedelingsaftalen fra 1564 var der klart tale om et $-\mathrm{i}$ juridisk forstand uberettiget krav fra Hans den Yngres side, så reelt set burde han intet have. Mæglerne foreslog ikke desto mindre, at de stridbare bønder deltes i to halvdele og at de øvrige omtalte bønder gik til kongen. Dermed havde man blot foreslåt en anden fordeling af bønderne end hidtil. Dette skulle hæve enhver tvivl om, hvor de respektive bønder hørte til og dermed løse problemet med de mange ulydige bønder $i$ Hans den Yngres tjeneste.

Selv om mæglerne havde fremsat et regulært kompromis, der med sine krav og indrømmelser til begge parter skulle kunne gøre ende på den årelange strid, så ville Frederik II ikke acceptere forslaget. Kongen fremhævede, at han havde 
lovet at betale Hans den Yngres tyske rigs- og kredsskatter i sin levetid. Derfor ville han have lov til at beholde sine velerhvervede og klart forbeholdte rettigheder. ${ }^{56}$

Til trods for pres fra mæglerne og hertug Hans den Yngre ${ }^{57}$ blev afvisningen endeligt fastslået $\mathrm{i}$ oktober samme år. Kongen ønskede ikke at forhandle mere om denne sag, ${ }^{58}$ og det blev der da heller ikke i de nærmest følgende år.

\section{Forliget $i 1579$}

Trods de stille år havde Hans den Yngre imidlertid ikke glemt sine ønsker om den gejstlige jurisdiktion såvel som kongens gods på Als og \#rø.

I forbindelse med Frederik IIs besøg på Sønderborg Slot i februar 1579 stillede Hans den Yngre et forslag om, at hertugen fik det kongelige gods i forlening - som i enkedronning Dorotheas levetid var lagt til Sønderborg Slot, men sidenhen var taget tilbage af kronen - for sig selv og sine arvinger mod at tjene riget med et antal udrustede heste. ${ }^{59}$

Resultatet blev, at Hans den Yngre i åbent brev af 31. marts 1579 fik livsbrev på det omtalte gods, som skulle være frit for al afgift, tynge og tjeneste under forudsætning af, at hertugen skriftligt forpligtede sig til, at godset efter hans død straks skulle falde tilbage til kronen. Desuden skulle han love, at han ikke ville beskæftige sig med den gejstlige jurisdiktion på øerne eller lægge den fynske biskop eller dem, som biskoppen satte til at høre kirkeregnskaberne på øerne, nogen hindringer i vejen. Skulle hertugens arvinger til sin tid mene sig berettiget til godset, så kunne de søge deres ret, når de havde afstået godset. ${ }^{60}$

Få dage senere bad Hans den Yngre om, at der måtte blive udstedt en revers med alle bøndernes navne opført, ${ }^{61}$ hvilket Frederik II nok kunne se god mening i. ${ }^{62}$ Hertugen ville antagelig sikre sig mod ethvert tvivlstilfælde, efter de dårlige erfaringer i begyndelsen af $1570^{\prime}$ erne. Hans den Yngre fremsendte derefter et udkast til reversen, ${ }^{63}$ hvori det tydeligt fremgik, at godset skulle tilfalde kronen ved hertugens død, og at den gejstlige jurisdiktion som hidtil tilhørte kongen via Odense Stift. Disse to kongelige forbehold blev også udtrykkelig anført $\mathrm{i}$ det af kongen udstedte livsbrev. ${ }^{64}$

Dermed havde hertugen på livstid opnået brugsretten til det - siden moderens død - så omstridte gods på Als og Ærø. Det drejede sig om ikke mindre end 150 gårde og mindre ejendomme. ${ }^{65}$ En arvelig forlening var det til gengæld ikke blevet til. Hans den Yngre havde skriftligt måttet acceptere, at den gejstlige jurisdiktion på øerne tilhørte kongen, som yderligere understregede dette $i$ et brev af 25 . november 1579 til provster og præster på Als og Ærø. ${ }^{66}$

Historikernes dom over forliget i 1579 har været helt entydig: Hans den Yngre nåede ikke målet nærmere, når det gjaldt kirkehøjheden på Als og Ærø. Snarere tværtimod, for nu forelå der skriftlige dokumenter, hvori hertugen erklærede, at 
han ikke ville befatte sig med den gejstlige jurisdiktion på øerne. Als og Ærø var altså fortsat under den danske krone i kirkelig henseende. ${ }^{67}$ Ifølge C. F. Allen kunne hertugen simpelthen ikke forvente anden udgang på konflikten, når han ikke var anerkendt af stænderne som regerende fyrste. ${ }^{68}$ Hans den Yngre havde ingen rettigheder på grund af sin stilling som afdelt herre.

Spørgsmålet er imidlertid om sagen var helt så enkel som eftertiden har gjort den. Det er tidligere vist, hvordan hertugen i sine første år havde problemer med at fastholde sine bønder, fordi de - for at slippe for at yde hoveri gjorde hvad de kunne for at blive kongelige bønder. Hertugen havde altså et myndigheds- og autoritets-problem, som påvirkede den daglige godsdrift. Dette problem var mere påtrængende end spørgsmålet om kirkehøjheden, da det var godsdriften og ikke kirkehøjheden, som gav indtægterne til den fyrstelige husholdning. I erkendelse af kongens ubøjelighed overfor hertugens samlede ønsker om både gods og kirkehøjhed prioriterede han godsforøgelsen højest. En overtagelse af krongodset på livstid ville give Hans den Yngre større autoritet $i$ det lille hertugdømme, eftersom det ville betyde en godsejer mindre (Frederik II). Samtidig kunne godsdriften intensiveres.

Ved skriftligt at anerkende kongens ret til kirkehøjheden over Als og Ærø havde hertugen unægtelig lidt et nederlag. Nederlaget blev ikke mindre af, at Hans den Yngre gennem årene havde argumenteret med udgangspunkt i det lutherske fyrstekirkeideal. På en vis måde havde han accepteret at blive stækket som den selvstændige territorialfyrste han opfattede sig selv som; men ved at overtage krongodset på livstid, var der til gengæld givet en god økonomisk kompensation.

\section{Tiden 1580 til 1588}

\section{Arvedelingen efter Hans den Aldre}

Natten mellem 1. og 2. oktober 1580 døde hertug Hans den Ældre af et slagtilfalde på sit slot Hansborg. Hans den Fldre var ugift og efterlod sig ingen direkte arvinger. I forbindelse med fællesforleningen af Slesvig den 3. maj samme år var arvespørgsmålet forblevet åbent, fordi man under forhandlingerne ikke kunne enes om en løsning. ${ }^{69} \mathrm{Nu}$ var problemet højaktuelt. Uenigheden skyldtes, at kong Frederik II mente, at arvefølgen måtte være den almindelige i fyrstelen, nemlig at Hans den Ældres andel skulle deles lige mellem på den ene side hertug Adolf og på den anden side Christian IIIs arvinger: Frederik II og Hans den Yngre. Hertug Adolf mente derimod, at eftersom Slesvig var et dansk len, måtte arvedelingen foregå efter danske arvelove, hvorved Adolf ville få hele arven efter Hans den ÆEldre. 
Kurfyrst August af Sachsen, hertug Ulrik af Mecklenburg og landgrev Wilhelm af Hessen sendte kommissærer til at forestå mæglingen, og resultatet blev $i$ august 1581, at arven deltes efter tysk mønster. Hans den Eldres lande deltes altså sådan som kongen ønskede det, men hertugens rørlige efterladenskaber tilfaldt dog Adolf alene. ${ }^{70}$

På grund af Hans den Yngres manglende andel i fællesforleningen i Holsten havde Frederik II indhentet betænkninger fra retslærde for at få afklaret broderens berettigelse til at arve Hans den Fldres holstenske besiddelser. Disse var ikke specielt gunstige for hertugen, men ikke desto mindre ville kongen give Hans den Yngre en trediedel af hele arveparten. Kongen skulle selv have sin egen og den affundne broder, Magnus' andel.

Frederik II havde vel til gengæld håbet, at Hans den Yngre ville vise sig imødekommende overfor kongens delingsforslag; men det blev ingenlunde tilfældet. Efter nogen forhandling blev resultatet, at Hans den Yngre den 23. april 1582 fik klostrene Reinfeld og Ryd samt strøgods i Haderslev Amt, fordi det sekulariserede klostergods ikke strakte til hertugens fulde arveandel. ${ }^{71}$

Arvedelingen efter Hans den Fldre gav grundlaget for mageskiftet i 1584 mellem kongen og hertugen.

\section{Forhandlingerne forud for mageskiftet af 6. marts 1584}

Den 18. december 1583 mødtes kongelige og fyrstelige kommissærer i Sønderborg for at forhandle om et mageskifte mellem kongen og hertugen. Kongen skulle have det strøgods i Haderslev Amt, som hertugen havde fået i arv efter Hans den Ældre, medens Hans den Yngre skulle have kirkegodset på Als og Ærø, som han siden 1579 havde haft livsbrev på. ${ }^{72}$ Det var ikke første gang man forhandlede om sagen. $\mathrm{Nu}$ skulle man tale om godsindkomsterne for at anslå værdien i penge, så man kunne sammenligne godset og derved komme så tæt som muligt på et ligeligt bytte. De fyrstelige råder gjorde opmærksom på, at Hans den Yngre også ønskede, at den gejstlige jurisdiktion over kirkerne på Als og Ærø skulle indgå i mageskiftet, men de kongelige råder kunne imidlertid ikke tage stilling til dette spørgsmål, da deres befaling ved forhandlingen kun gik ud på at sammenligne godset. De fyrstelige råder gjorde desuden en stor indsats for at få det haderslevske strøgods vurderet så højt som muligt, så der kunne blive basis for den størst mulige godsforøgelse på Als og Ærø. ${ }^{73}$

På baggrund af forhandlingerne mellem de kongelige og fyrstelige råder $\mathrm{i}$ december 1583 skrev Hans den Yngre den 20. januar 1584 til Frederik II. Hertugen ønskede den gejstlige jurisdiktion på øerne i forbindelse med mageskiftet. Hans den Yngre og hans børn havde deres fyrstelige hovedresidens $i$ Sønderborg. Derfor ønskede han sig en kirke i byen, som skulle være begravelseskirke for hertugfamilien. Det irriterede imidlertid hertugen, at han 
ikke havde magt til at fjerne en dårlig præst og indsætte en bedre. Hans den Yngre måtte se passivt til, at kirkerne forfaldt, og at præsterne gjorde mere for at fremme deres egne sager end Guds! ${ }^{74}$

Frederik IIs svar fra 3. februar 1584 var som i de foregående år et afslag på broderens bøn om at få øernes gejstlige jurisdiktion. Frederik II var imidlertid ikke utilbøjelig til at overlade Hans den Yngre den gejstlige jurisdiktion over Sønderborg. ${ }^{75}$

I mellemtiden havde Hans den Yngre fået en ny idé: han og hans arvinger skulle have en medinspektionsret sammen med den fynske biskop over de alsisk-ærøske kirker. Motivationen var angiveligt kristelig omsorg, og dette forslag ville kunne realiseres, uden at der skete brud på kongens og rigets højhed over kirkerne. ${ }^{76}$ Kongen så dog ingen grund til at give Hans den Yngre en sådan medinspektionsret, når den fynske biskop skulle forhøre kirkeregnskaberne. Frederik II forordnede samtidig, at alle kirkeindkomsterne - tiende såvel som andre indtægter - alene skulle anvendes til kirkernes eget bedste, og at de ikke i mindste måde måtte forringes. Dermed var kirkekassen for Als og Ærø opstået. $^{77}$

\section{Mageskiftet af 6. marts 1584}

Den 6. marts 1584 afsluttedes mageskiftet mellem Frederik II og Hans den Yngre på Koldinghus. Kongen fik hertugens strøgods i Haderslev Amt, medens hertugen fik alt kongens og det danske riges gods på Als og $Æ r ø .{ }^{78}$ Dermed kom hele Ærø i Hans den Yngres besiddelse. Alt blev overtaget med fulde rettigheder og intet var udeladt - bortset fra den gejstlige jurisdiktion. I kraft af patronatsretten skulle den fynske biskop nu som før uhindret have opsynet med sjælesorg, udnævnelse og indvielse af præsterne, forhøring af kirkeregnskaberne og hvad der ellers fulgte med kirkehøjheden. Imidlertid bevilligede kongen overraskende nok, at også hertugen og dennes arvinger måtte forhøre kirkeregnskaberne. Tre uger i forvejen havde Frederik II ellers anset det unødvendigt.

Kirkehøjheden over Sønderborg blev overdraget til Hans den Yngre og hans efterfølgere. Desuden fik han den gejstlige jurisdiktion over de kirker han måtte ønske at bygge til Guds ære og til sit begravelsessted. ${ }^{79}$

Ifølge Johanne Skovgaard i Sonderborg Bys Historie, kan den omtalte begravelseskirke kun være slotskirken på Sønderborg Slot. Den lidt uklare formulering skulle angiveligt sløre den omstændighed, at kirken allerede var bygget $\mathrm{i}$ enkedronningens tid og næppe nogensinde havde hørt under andet end hertugelig jurisdiktion. Desuden fik Hans den Yngre højheden over sognekirken, Sankt Jørgens Kirke - senere kaldet Mariekirken. Sønderborg blev herefter taget ud af det alsiske provsti og tillagt provsten i Sundeved. Efter Johanne Skovgaards opfattelse betød denne udskillelse ikke alene en svækkelse af 
det danske sprogs stilling på langt sigt, men byen mistede - i modsætning til de øvrige alsiske præster og bønder - også adgangen til at få kongens hjælp overfor hertugens hårde styre. ${ }^{80}$

Med mageskiftet var der virkelig sket et skred i udviklingen. Det tidligere kirkegods, som kongen i 1579 havde overladt Hans den Yngre på livstid, var nu givet til hertugen som arvelig ejendom. Det var væsentligt for hertugens stilling som landsherre på Als og Ærø. Mindreværdskomplekser eller spørgsmålet om autoritet og myndighed spillede jo - som tidligere anført - en ikke uvæsentlig rolle i forbindelse med de problemer som Hans den Yngre havde i sine første år som regerende hertug og godsejer.

Med hensyn til den gejstlige jurisdiktion havde kongen givet efter på to områder: kirkehøjheden over Sønderborg og medopsynsretten over kirkeregnskaberne på Als og Ærø. For begge områder gælder det, at Frederik II havde brudt med sin ellers så konsekvente afvisning af enhver indrømmelse. Den lange kirkestrid havde dermed givet et konkret resultat - og måske også håb om mere?

Men hvorfor slækkede Frederik II på kirkehøjheden? Nogen direkte forklaring giver kilderne ikke, men forskellige faktorer kan have spillet ind.

Peter Langendorf mener, at Hans den Yngre utvivlsomt havde ret, når han den 20. januar $1584 \mathrm{i}$ et brev til kongen klagede over den dårlige præstestand på Als. Biskoppen boede jo langt væk og visiterede sjældent. Desuden hørtes tilsvarende kritik fra de kongelige gesandter. ${ }^{81}$ Kongen kan med andre ord være blevet klar over, at der vitterlig var et problem med kirkerne på de to øer. Dertil kommer, at kirkestriden efterhånden var blusset op gentagne gange, og at en kompromisløsning derfor ville være at foretrække fremfor fortsat strid.

I 1579 havde hertugen ved forliget anerkendt kongens højhedsret over øerne. I den sammenhæng er det karakteristisk for argumentationen i januar og februar 1584, at den koncentrerer sig om kirkernes faktiske tilstand på øerne, medens det lutherske fyrstekirkeideal - som der $\mathrm{i}$ høj grad blev lagt vægt på $\mathrm{i}$ de tidligere år - er blevet nedtonet. Præsterne manglede simpelthen et effektivt opsyn i mere umiddelbar nærhed.

Endelig kan man pege på, at Frederik II i tilknytning til det ovenstående har fundet Hans den Yngres ønske om fuld jurisdiktion i Sønderborg rimeligt, da byen var det lille hertugdømmes hovedstad. I håbet om ro på kirkehøjhedsfronten var det jo heller ikke nogen høj pris i betragtning af, at det øvrige Als - bortset fra Egen - og hele Ærø stadig var i kongelig besiddelse.

\section{Baggrunden for Frederik IIs politik}

Den 4. april 1588 døde kong Frederik II på Antvorskov. Siden mageskiftet i 1584 havde der været ro omkring det alsisk-ærøske kirkehøjhedsspørgsmål. 


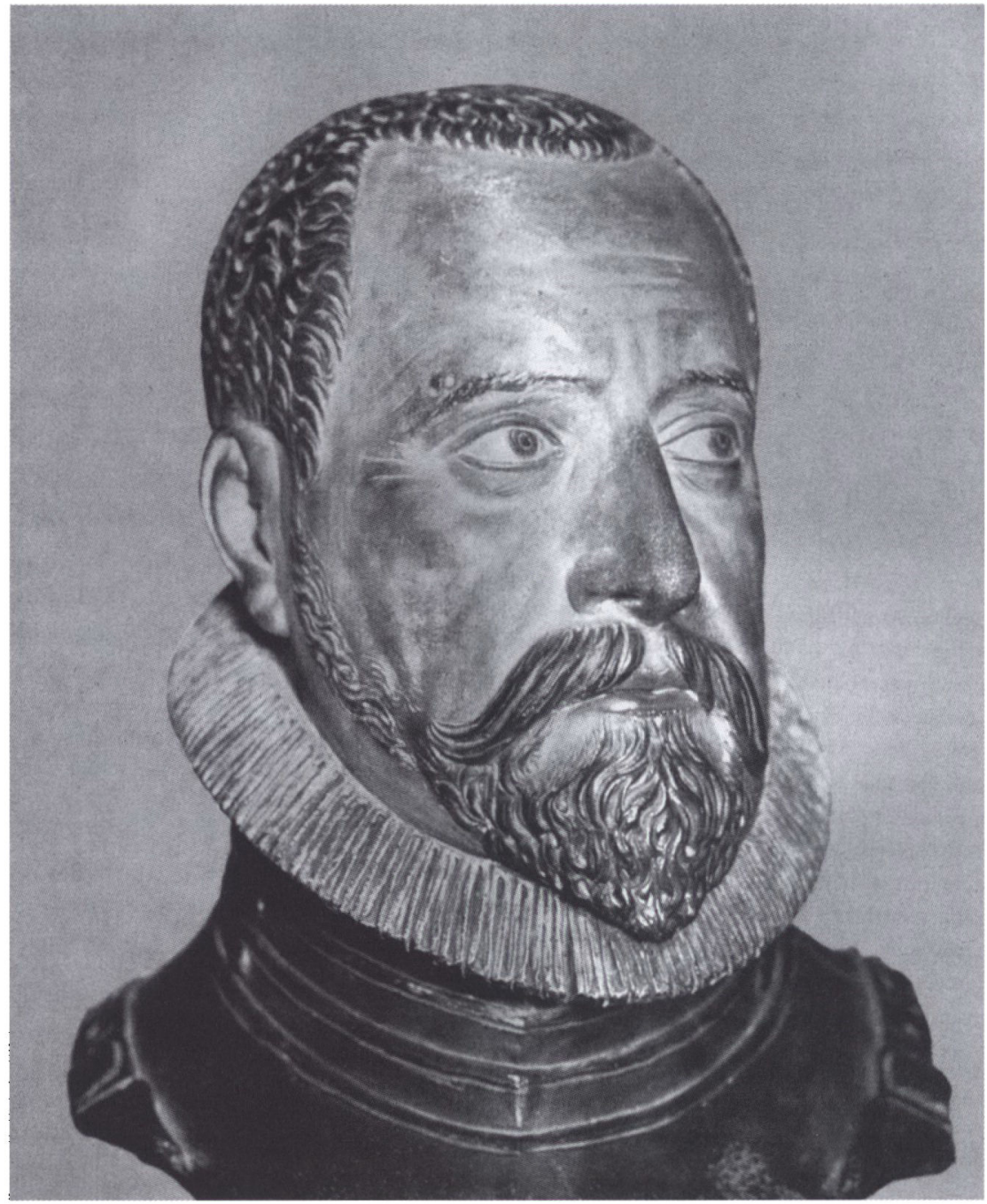

Kong Frederik II (1534-1588) stod roligt og sikkert fast pd Danmarks Riges velerhvervede rettigheder, når det gjaldt den gejstlige jurisdiktion over Als og Are. De indrommelser han gav. fik ikke vidtrakkende folger, men var trods alt med til at dampe striden $i$ kongens sidste leveår. Bemalet buste af brandt ler. 1578. Frederiksborgmuseet.

Kilderne er påfaldende tavse angående den egentlige baggrund for den kongelige politik. Frederik II påberåber sig gang på gang sine juridiske og historiske rettigheder, men motiverer dem ikke på anden måde, end at han ikke kan tillade en forringelse af det danske riges højhed. 
Stridens langvarige forløb og de mange forhandlinger viser imidlertid, at spørgsmålet må have haft en særlig betydning for kongen. Denne betydning understreges af, at der sideløbende med Hans den Yngres krav om kirkehøjhed også eksisterede en tilsvarende - og ligeså langvarig - uenighed mellem Frederik II og Hans den Ældre. Hans den Fldre mente, at stiftsøvrighedens afgrænsning skulle svare til den verdslige administrations grænser. Store dele af Hans den Ældres hertugdømme hørte i kirkelig henseende til Ribe Stift, som var et dansk stift $\mathrm{og}$ underlagt kongeriget. De berørte områder var hele Tørning Len, Tønder by og af Tønder Amt: Tønder, Højer og Lø herreder. Der blev forhandlet om problemerne i årene fra 1576 til 1578. Resultatet blev, at kongens svoger, kurfyrst August af Sachsen, fældede en voldgiftsdom, som - uagtet de fra kongelig side fremførte kirkeretlige og historiske synspunkter - tilkendte Hans den Ældre den gejstlige jurisdiktion, idet han gik ud fra den lutherske regel om, at kirkehøjheden fulgte landshøjheden. Da Hans den Ældre døde i 1580, arvede Frederik II Tørning Len og ordningen bortfaldt igen. ${ }^{82}$.

Fællesnævneren for Hans den Ældres og Hans den Yngres strid med kongemagten er, at begge hertuger havde besiddelser i danske stifter: Ribe og Odense. Derfor gjaldt den danske kirkelovgivning her som andre steder $\mathrm{i}$ kongeriget. ${ }^{83}$ Erslevs grundige behandling af de statsretlige forhold i Slesvig og Holsten viser blandt andet, at stænderne betragtede de to hertugdømmer som en helhed, medens fyrsterne betragtede det som deres familiearv. ${ }^{84}$ Kongen var imidlertid ikke interesseret $i$ en fuldstændig opsplitning af sit danske len Slesvig. Ernst Feddersen har peget på, at kongen - i hvert fald med hensyn til Als og Ærø - havde en dynastisk interesse $i$ at bevare en vis indflydelse i de udskilte områder ved hjælp af den danske biskop. ${ }^{85}$

De to parallelle sager med henholdsvis Hans den Fldre og Hans den Yngre som kongens modspiller viser, at den opfattelse som C. F. Allen i 1857 gjorde sig til talsmand for, ikke kan opretholdes. Allen mente nemlig, at Hans den Yngre ikke var berettiget til nogen kirkehøjhed på grund af den manglende arvehyldning. ${ }^{86}$ Hvis dét var det afgørende for stridens udfald, så burde den ikke også kunne føres mellem kongen og Hans den Aldre, som jo netop var hyldet som regerende fyrste. Synspunktet modsiges desuden af, at kongen samtidig gjorde meget for at få sin broder anerkendt som fyrste på linie med de øvrige hertuger.

Fra et kongeligt udgangspunkt var stridens kerne med andre ord, at kongen ikke ville afgive den indflydelse han havde $\mathrm{i}$ hertugdømmernes yderområder $\mathrm{i}$ kraft af, at Ribe og Odense stifter strakte sig ind på slesvigsk jord. Det var Frederik IIs eneste retmæssige måde at gøre sig gældende indenfor hertugdømmerne på. Derfor gjaldt det så meget mere om at holde fast på denne nedarvede rettighed. 

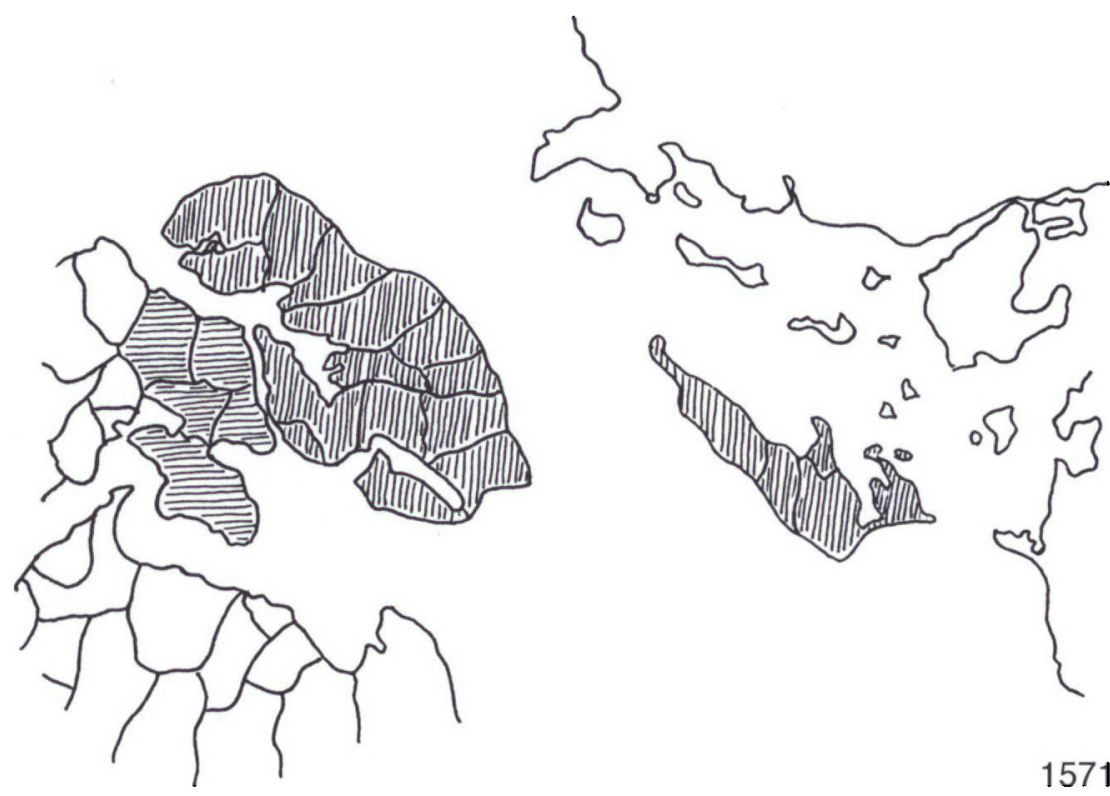

1571

De to korts skraverede felter viser Hans den Yngres besiddelser $i$ henholdsvis 1571 ved enkedronningens dod og $i 1622$ ved hertugens dod. Den lodrette skravering angiver omrddet med Odense Stifts kirkehojhed og den vandrette skravering viser hertugens provsti. I 1571 har Hans den Yngre kun hojheden over de fem sogne pd Sundeved: Ullerup, Sottrup, Nybol. Dybbol og Broager. I 1582 ved arveinddelingen efter Hans den Aldre far Hans den Yngre kirkehøjheden over Egen pd Als samt Glücksborg og Munkbrarup. Ved mageskiftet af 6 . marts 1584 erhverves den gejstlige jurisdiktion over Sonderborg. Pd grundlag af mageskiftet kan hertugen desuden fä kirkehojheden over Kegnas ved kirkens opforelse $i$ 1615. Endelig udvides provstiet i 1621-1622 med opforelsen af Nykirke i Angel. Den afsluttende fordeling fremgdr af kortet fra 1622.

Men hvad skulle indflydelsen bruges til?

Én ting var at have indflydelse på valg af præster og provster. Kirkeordinansen skulle følges her som i Danmark. Kirkerne kunne kontrolleres ved hjælp af biskoppens visitation på øerne og forhøring af kirkeregnskaberne; men lå der mere bag?

I Hans den Yngres argumentation går det, som tidligere vist, lige fra 1571 som en - mere eller mindre klar - rød tråd, at han fordrede kirkehøjheden for at være ligeværdig med de øvrige fyrster og for at kunne indgyde respekt blandt undersåtterne. Det handlede $\mathrm{i}$ bund $\mathrm{og}$ grund om autoritet og myndighed. Hans den Yngre søgte bestandig at understrege sin høje værdighed og styrke sin lutherske selvopfattelse - måske fordi rollen som afdelt herre inderst inde gav et mindreværdskompleks. Dette sandsynliggør, at Hans den Yngre blandt andet skulle bruge kirkehøjheden til at få lydige undersåtter ${ }^{87}$ Kirken skulle bidrage til disciplineringen. 

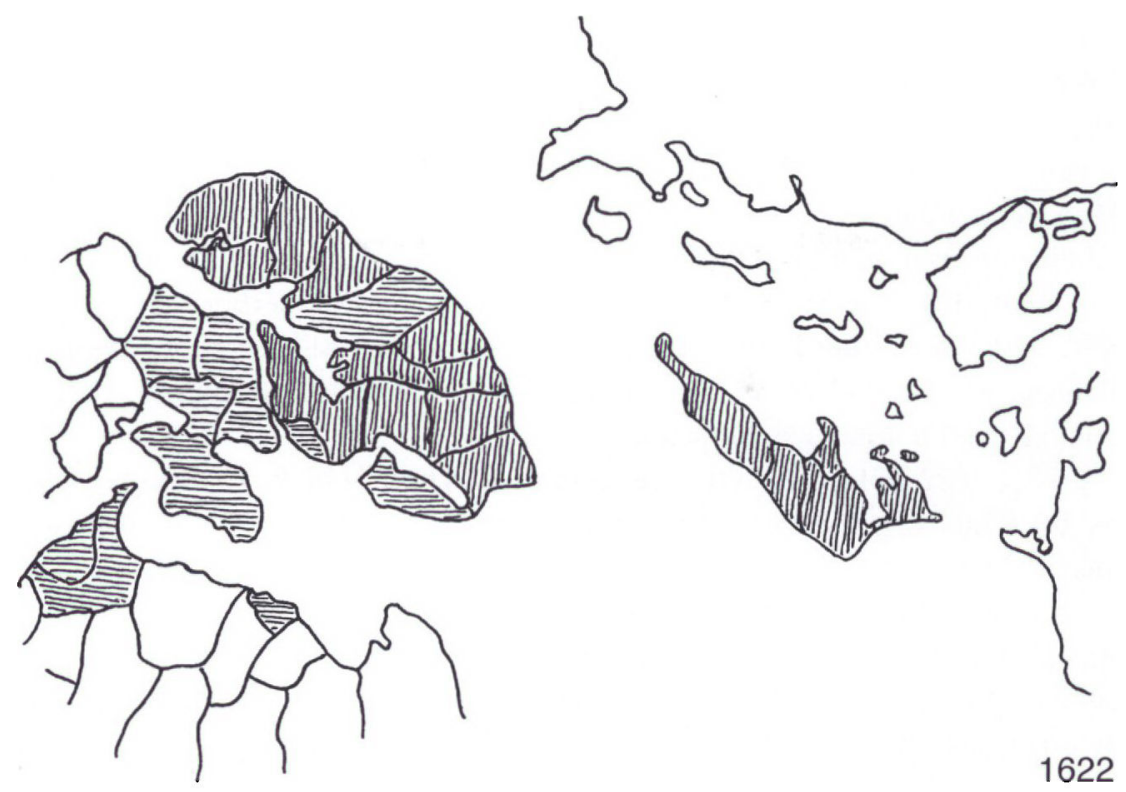

For kongens vedkommende har det været de samme årsager, der gjorde sig gældende. Ved hjælp af kirken - især via kirketugten - kunne Frederik II få indflydelse på styringen af undersåtterne og dermed bevare en ikke ubetydelig indflydelse på Hans den Yngres lille hertugdømme.

\section{Hans den Yngres provsti ${ }^{88}$}

Ved arvedelingen i 1564 fik Hans den Yngre blandt andet Sundeved. Til forskel fra Als og Ærø hørte dette område ikke til Odense Stift, men til Slesvig Stift.

Enkedronning Dorotheas provst, Johann Berndes i Broager, måtte i efteråret 1571 give afkald på sit alsiske provsti, men kunne til gengæld beholde den del af provstiet, som lå i Sundeved. Dette provsti regnedes til hertugdømmet og var en del af Slesvig Stift. ${ }^{88}$ Kirkerne på Sundeved var Nybøl, Broager, Ullerup, Sottrup og Dybbøl. ${ }^{90}$ Inden Berndes døde i april 1596, blev provstiet imidlertid udvidet flere gange. I forbindelse med arven efter Hans den Ældre i 1582, overtog Hans den Yngre højheden over kirken i Egen. Kirken havde inden reformationen hørt under Ryd Kloster. Efter reformationen havde landsherren - det vil indtil 1582 sige kongen - patronatsretten. Hans den Yngre overtog kirkehøjheden, da han fik Ryd Kloster. ${ }^{91}$ I Munkbrarup - som også havde hørt under Ryd Kloster ${ }^{92}$ - lod Hans den Yngre kirken genopføre i 1582 . Den var i 1565 blevet ramt af en lynbrand og havde siden stået som ruin. ${ }^{93}$ 
Hvor det nedrevne Ryd Kloster havde ligget, lod Hans den Yngre i årene 1582-1587 Glücksborg Slot opføre. Også slotskirken kom under Berndes' tilsyn. ${ }^{94}$

Bortset fra kirken i Egen ligger alle de hidtil nævnte kirker uden for Als. Med mageskiftet af 6 . marts 1584 blev forudsætningen for provstiets alsiske udvidelser givet, idet hertugen fik højheden over Sønderborg og over de kirker han fremtidigt ville bygge. I første omgang udskiltes Sønderborg fra Odense Stift og lagdes til det hertugelige provsti. ${ }^{95}$ I forbindelse med bebyggelsen af Kegnæs på Als, lod Hans den Yngre i 1615 Kegnæs Kirke opføre. Kirken opkaldtes efter Johannes Døberen.

I 1621-1622 opførtes - efter de samme tegninger - Nykirke (Neukirchen) øst for Flensborg. Bønderne fra Sundeved og Als bragte sten og tømmer sammen til byggeriet. ${ }^{96}$

På grund af Sønderborgs og Kegnæs' tilknytning til Hans den Yngres provsti, var disse sogne i de følgende århundreder underlagt den slesvigske superintendent. Først i 1864 ophørte denne særstilling, idet tabet af hertugdømmerne betød, at hele Als kom under Slesvig Stift. Efter 1920 udskiltes den danske del af Slesvig Stift som en del af Haderslev Stift.

\section{Tiden 1588 til 1622}

\section{Hans den Yngre fatter nyt håb om kirkehojheden}

Efter Frederik IIs død i april 1588 indsattes der som følge af Christian IVs unge alder - kun 11 år - et formynderstyre bestående af fire rigsråder. ${ }^{97}$ Det blev anledningen til, at Hans den Yngre samme år - eller måske snarere året efter - sendte et brev til rigsråderne angående den gejstlige jurisdiktion på Als og Ærø. Nu ville hertugen have gjort ende på misforståelsen og med de nødvendige beviser dokumentere, at hans forfadre i deres egenskab af hertuger af Slesvig havde disponeret over den gejstlige højhed og patronatsretten. Havde Frederik II levet længere, ville der have været gode chancer for, at Hans den Yngre havde fået kirkehøjheden tilbagegivet(!). ${ }^{98}$

Den 12. november 1588 skrev formynderstyret til Hans den Yngre angående de alsiske kirkers mangler. ${ }^{99}$ Hertugen svarede $i$ begyndelsen af december, at formynderstyret kun kunne takke sig selv for kirkernes dårlige tilstand, eftersom de ikke ville afgive kirkehøjheden til hertugen. ${ }^{100}$

Hans den Yngre havde dermed taget en chance og markeret sig skarpt overfor formynderstyret. Det bevirkede imidlertid, at den kongelige mistænksomhed voksede. Det blev understreget, at den kongelige kirkehøjhed over Als og Ærø skulle fastholdes via den fynske biskop. Desuden skulle vidtløftige 
diskussioner om højhedsrettigheder undgås. ${ }^{101}$ Med andre ord: Hans den Yngres taktik havde slået fejl.

\section{Kongelig visitation på Als og Aro september 1589}

Den 31. juli 1589 fik den fynske biskop Jacob Madsen ${ }^{102}$ og embedsmanden på Nyborg Slot, Laurits Brockenhus til Brangstrup, besked om at tage til Als og Ærø for at visitere kirkerne. ${ }^{103}$ Visitationen skulle finde sted inden Sankt Mikkels dag (29. september) eller straks derefter. Madsen og Brockenhus skulle undersøge kirkernes regnskab, ${ }^{104}$ tilstand og tilgodehavende. De af Hans den Yngres bønder, som skyldte kirkerne noget og de, der var - eller havde været - kirkeværger, skulle beordres samlet til regnskabsaflæggelse. Alle præster og kirkeværger på begge øer skulle møde frem, for at visitatorerne kunne få afklaret, om alt foregik som kirkeordinansen foreskrev. ${ }^{105}$ Var det ikke tilfældet, skulle der rådes bod på det.

Hertugens skrappe brev til formynderstyret var måske nok dråben, der fik bægeret til at flyde over, men $\mathrm{i}$ bund og grund var den udførlige visitationsinstruks utvivlsomt en udløber af den mangeårige strid om kirkehøjheden på øerne. Regeringen fandt det nødvendigt straks at markere en skarp og konsekvent linie, hvis Christian IV skulle undgå at marve« striden efter sin far.

Madsen og Brockenhus ankom til Als den 15. september 1589. Om aftenen nåede de til provstens hus. Provsten blev syg kort efter deres ankomst og var døden nær næste dag. Visitatorerne fandt ingen besked i huset, som kunne hjælpe dem med at udføre den pålagte instruks.

På andendagen tog de til Sønderborg, hvor de bad Hans den Yngre om at samle borgere, bønder, kirkeværger og andre, som skyldte kirkerne noget. Også Hans den Yngre skyldte kirkerne en del. I årene hvor Frederik II og hertugen havde diskuteret, hvem der skulle have patronatsretten til kirkerne, havde hertugen oppebåret kirketienden af sine tjenere og bønder, men havde ligesom adelen - beholdt pengene. Madsen og Brockenhus belærte derfor hertugen om, at hverken adelen eller han selv måtte beholde den opkrævede tiende. Den skulle snarest muligt gives til kirkerne.

Derefter tog visitatorerne ud til hver kirke, hvor de kunne konstatere, at ritualerne var fuldstændig magen til de øvrige danske kirkers. Her og der manglede en bog, men den skulle biskoppen - for kirkernes penge - nok sørge for at skaffe. Præsterne blev befalet $i$ alle måder at overholde kirkeordinansen.

Regnskaberne for årene 1570 til 1581 blev gennemgået og viste, hvad hertugen, adelspersoner, borgere og bønder skyldte. På grund af det lange tidsrum var der naturligt nok skyldnere, som var døde - nogle uden arvinger. Nogle var flyttet, nogle steder var lagt øde og lagt til hertugens avlsgård. Nogle penge kom dog ind og de resterende beløb opførtes i en bog i hver kirke. De hidtidige 


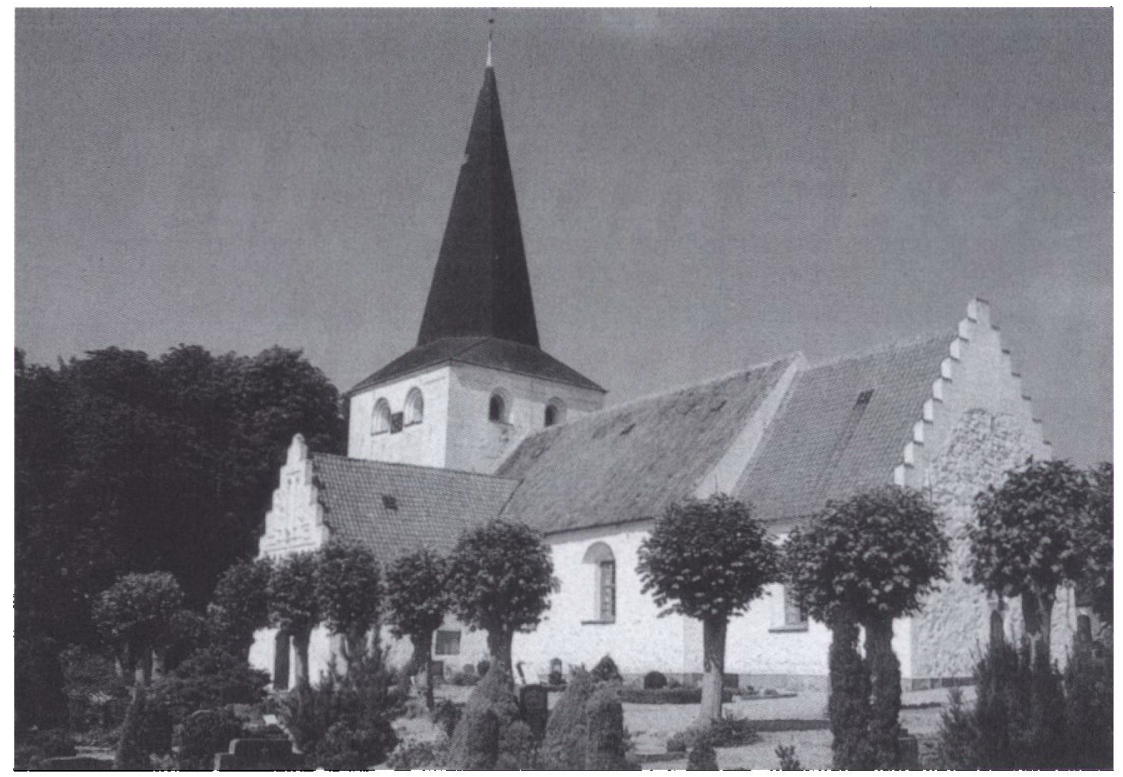

Bregninge kirke pd Aro med det imponerende ostslesvigsk pragede spir. Ved Jacob Madsens og Laurits Brockenhus'visitation pà Aro i september 1589 var spiret i darlig forfatning, men da alle kirkens penge var blevet stjålet i foråret, ville bygmesteren ikke indgd aftale om reparation, for den aktuelle gaild til kirken var indkravet. Postkort.

kirkeværger havde ifølge instruksen været forsømmelige i opkrævningen - eller bange for at stille krav til deres husbond eller hans tjenere. Derfor skulle sognepræsten og en af de formuende mænd i sognet fra nu af være kirkeværger.

Jacob Madsen og Laurits Brockenhus tog en bygmester med rundt i de alsiske og ærøske kirker for at tage manglerne i øjesyn. Et særligt problem udgjorde Bregninge Kirke på Ærø. Spiret var meget forfaldent, men da alle kirkens penge var blevet stjålet $\mathrm{i}$ foråret, ville bygmesteren ikke indgå nogen aftale om udbedringer, før den aktuelle gald til kirken var indkrævet.

Søndagen før Sankt Mikkels aften visiterede Madsen og Brockenhus de ærøske kirker. Hans den Yngre var samtidig på jagt på øen og indbød biskoppen og stiftslensmanden til at spise med i sit jagthus Graasten. Under spisningen talte de blandt andet om kirkerne. Visitatorerne bevilligede, at hertugens åbne brev fra $1586^{106}$ - om at alle skulle betale, hvis de skyldte kirkerne noget fortsat kunne stå ved magt.

Næste dag gjorde hertugens sekretær, Johannes Hildesheim, opmærksom på, at kong Frederik II havde tilladt, at en hertugelig skriver måtte overvære forhøringen af kirkeregnskaberne, da det var rimeligt, at hertugen vidste om hans undersåtter betalte det de skulle til kirken og hvad pengene blev brugt 
til. ${ }^{107}$ Jacob Madsen og Laurits Brockenhus kendte ikke til dette særlige vilkår. Instruksen meddelte intet herom, men de lovede at lade oplysningen gå videre. ${ }^{108}$ Hertugen var imidlertid tilfreds med visitationens forløb. ${ }^{109}$

Reparationerne på de alsiske kirker og på Rise og Tranderup kirker på Ærø blev herefter overladt til Peder Murermester i Sønderborg. På grund af materiale- og løn-omkostninger var det vigtigt, at adelens og hertugens gæld til kirkerne blev indkrævet. Af det summariske regnskab over hertugens og adelens gæld til kirkerne på Als og Ærø fremgår det, at Hans den Yngre skyldte kirkerne på Als 1.839 mark og 11 skilling, medens han på Ærø skyldte kirkerne 11 læster, 2 ørtug og 1 1/2 skæppe korn. Til sammenligning var den næststørste skyldner fru Berte Sture, hvis gæld lød på 641 mark, 6 skilling og 8 penning. ${ }^{10}$

Visitationsrejsen var ikke forgaves: fra og med dette år blev kirkeregnskaberne lovformeligt ført for alle kirkerne på de to øer. ${ }^{11}$ Samtidig havde formynderstyret vist, at de i spørgsmålet om den gejstlige jurisdiktion lå på linie med Frederik IIs konsekvent gennemførte politik i den mangeårige strid. Men Hans den Yngre opgav ingenlunde kampen.

\section{Hans den Yngres "kupforsog"}

I slutningen af juli måned 1590 skrev Hans den Yngre en instruktion til sine gesandter, som skulle deltage ved den danske rigsdag i Kolding. Her skulle de forhandle med de kongelige regerings- og rigsråder. Hertugen gav dem fuldmagt til at forhandle sin sag om den gejstlige højhed på Als og Ærø. Det bærende argument $\mathrm{i}$ denne nye anmodning var - ligesom tidligere - at den kongelige families forfædre ikke havde haft den fulde lands- og kirkehøjhed $i$ området fordi de var konger af Danmark, men derimod i deres egenskab af hertuger af Slesvig. ${ }^{112}$ Frederik IIs enkedronning Sophie fik et brev med tilsvarende indhold. Antagelig for, at hun skulle gøre sin indflydelse galdende overfor formynderstyret, ${ }^{113}$ som også blev tilskrevet. Hans den Yngre betonede, at ingen $i$ det Tysk-Romerske Rige ville nægte adelen den fulde højhed $i$ deres områder. Det skulle vel ikke være ringere at være lensmand under den danske krone? ${ }^{114}$ Hertugens krav var således meget klare, men der synes ikke at være kommet noget ud af henvendelsen.

Under et ophold på Søbygaard på Ærø tog hertugen den 28. september 1590 et helt nyt skridt: han skrev til den alsiske provst, Jacob Pilegaard i Hørup, ${ }^{115}$ og den ærøske provst, Peter Knudsen i Bregninge, ${ }^{116}$ og befalede dem at forhøre kirkeregnskaberne på øerne. Da hertugen var arveberettiget til højheden på øerne, kunne han ikke tillade, at den fynske biskop skulle forhøre kirkeregnskaberne dér. Provsterne skulle sørge for indsamling af kirkekornet og sikre, at gudstjenesterne foregik som de skulle. Alt skulle ske til kirkernes 


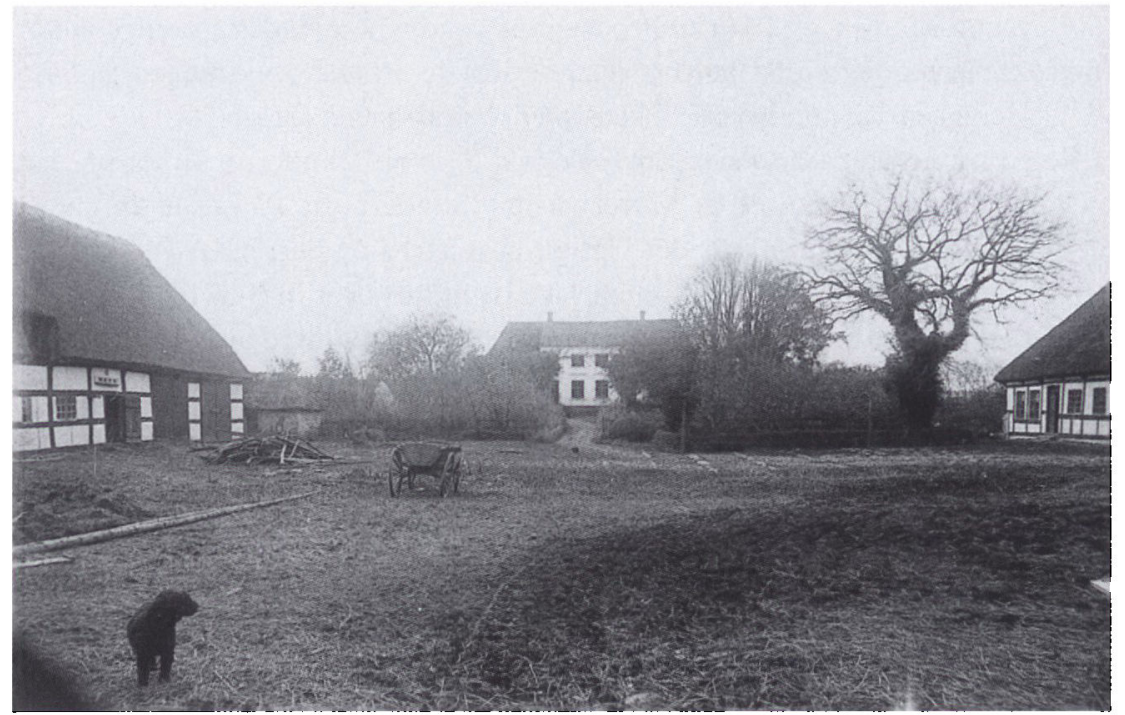

Omkring 1580 opforte Hans den Yngre Sobygaard pd Aro. Hovedbygningens stenkalder er - ligesom dele af ladegdrden - bevaret fra Hans den Yngres tid. Fotografi fra ca. 1910 i Eroskobing Kommunes Lokalhistoriske arkiv.

bedste. Hans den Yngre ønskede derefter at modtage et regnskab og register. Hertugen ville fortsat anerkende Pilegaard og Knudsen som provster. ${ }^{17}$

I mageskifteaftalen fra 1584 var det blevet bestemt, at såvel den fynske biskop som Hans den Yngre - og senere også arvingerne - måtte lade kirkeregnskaberne forhøre. ${ }^{118}$ Men når Hans den Yngre nu ikke længere kunne tillade, at den fynske biskop forhørte kirkeregnskaberne, så gik han et godt stykke over stregen. Hans den Yngre indlod sig her på en principiel kritik af biskoppen som tilsynsmyndighed.

Brevet til den ærøske provst kom tilsyneladende ikke til rigsrådets kendskab, men det gjorde brevet til provsten på Als! Derfor skrev formynderstyret den 20. oktober 1590 til Laurits Brockenhus og Jacob Madsen - som tidligere havde visiteret på Als og Ærø - og bad dem møde personligt i Kolding den 28. oktober, hvor formynderstyret og rigsråderne ville være til stede. Her skulle der tages beslutning om, hvordan man skulle reagere på Hans den Yngres fremfærd. Hertugen havde jo ønsket at forhøre kirkernes regnskaber på Als og det stred mod kronens højhed. Desuden fik Brockenhus som stiftslensmand besked om at meddele provsten på Als, at denne ikke måtte forhøre noget kirkeregnskab på øen uden Brockenhus' og biskop Madsens vidende og befaling. ${ }^{119}$

Efter mødet i Kolding blev der udfærdiget en instruks til Henrik Below og 
Albert Friis. De skulle tage til Sønderborg og overfor Hans den Yngre fastslå den danske krones ret til kirkehøjheden over Als og Ærø. Instruksen indeholdt en gennemgang af den langvarige strid, men selv om mageskiftet af 6. marts 1584 også var nævnt, så var aftalen om Sønderborgs særstatus samt hertugens ret til at forhøre kirkeregnskaber udeladt. ${ }^{120}$ Dermed var der set bort fra enhver formildende omstændighed: Hans den Yngre havde forløbet sig og skulle have en kraftig irettesættelse!

Den 11. november 1590 gav en ydmyg Hans den Yngre sin uforbeholdne undskyldning til formynderstyret. Samtidig lovede hertugen at lade kirkehøjhedsspørgsmålet hvile så længe Christian IV var mindreårig. ${ }^{121}$ Hans den Yngre havde taget en chance og havde tabt. Rigsråderne havde taget striden i opløbet, for at undgå forringelser i den danske krones højhed og rettighed.

\section{Forhandlingerne i 1609}

I 1596 overtog Christian IV regeringen, og striden om kirkehøjheden kunne $i$ henhold til aftalen fra november 1590 - blive endelig afgiort. Der skulle dog gå nogle år, inden spørgsmålet igen blussede op. ${ }^{122}$

Den 13. marts 1605 opregnede Christian IV $i$ et brev til Jacob Rosenkrantz en række klager til kongen fra kirketjenere og andre undersåtter på Als og Ærø. Det var klager over Hans den Yngre, som tiltog sig jorder og ejendomme, som præsterne havde haft i brug og som hørte under kongeriget. Flere bønder var blevet frataget deres retmæssige arv og ejendom, som de havde tidligere danske kongers brev på. For synets skyld blev det gjort ved dom, men af hertugens egne tilforordnede fogeder! Jacob Rosenkrantz fik til opgave at undersøge og optegne klagerne fra de alsisk-ærøske undersåtter. En fortegnelse skulle derefter indsendes til kancelliet, som ville overveje, hvordan sagen kunne løses. ${ }^{123}$

Klagerne var ret ensartede: kirker og præster var forarmede på grund af de mange bønder, som forsømte at betale deres tiende til tiden. Nogle døde inden de fik betalt, medens andre flyttede. Præsterne anmodede om, at skyldnerne blev pålagt at give tiende som kirkeordinansen foreskrev. Præsterne klagede desuden over den bytning af kirkejorden, der fandt sted mellem bønderne. ${ }^{124}$

Et hyppigt klagepunkt var, at præsterne simpelthen ikke fik den landgilde af kirkejorden som de rettelig tilkom. I Rise sogn på Ærø havde hertugens fogeder fradømt præsten to marker. Hertugen tilsåede selv en mark og kunne derfor - på baggrund af adelsprivilegierne fra $1536^{125}$ - undlade at betale tiende til præst og kirke. ${ }^{126}$ Kort sagt sørgede hertugen for sig selv og sine og lod kirkerne i stikken! Hans den Yngre ville utvivlsomt presse kongen til at afgive kirkehøjheden; men metoden virkede åbenlyst omvendt, da Christian IV på denne baggrund jo slet ikke kunne overlade de kongelige kirker på Als 


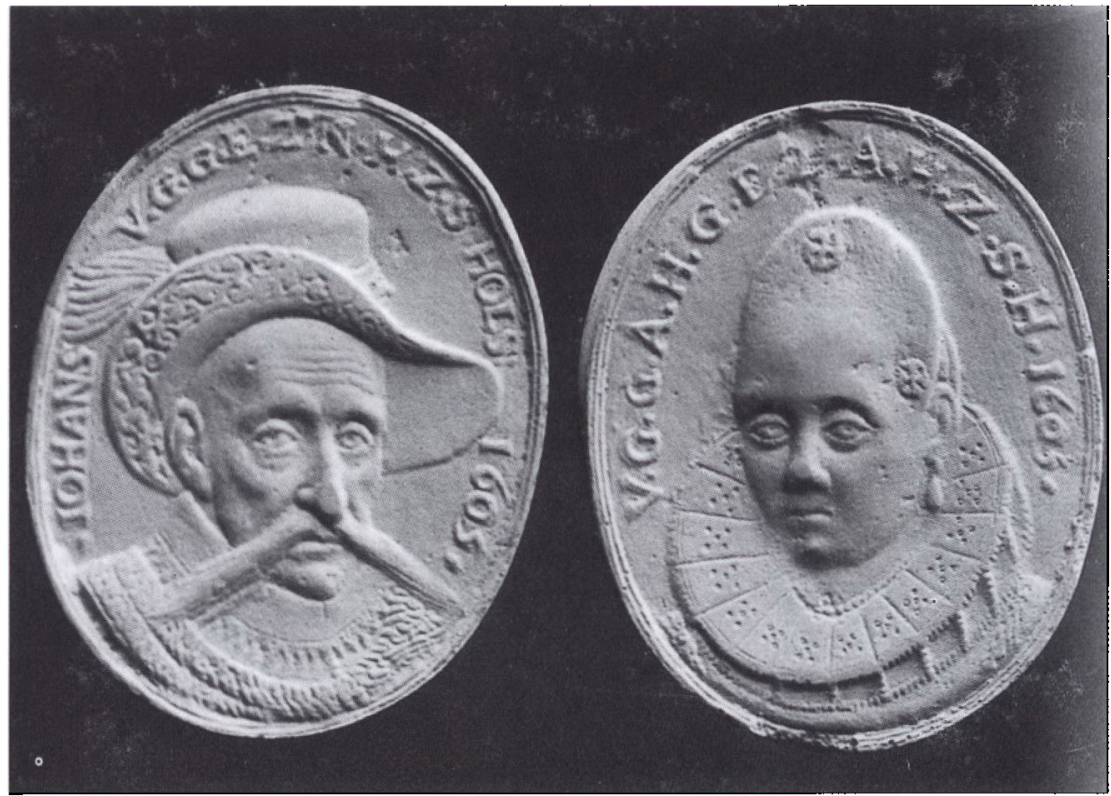

Hans den Yngre og hans anden gemalinde. Agnes Hedwig, enke efter kurfyrst August af Sachsen. Portratmedaljer 1605. Fotos i Institut for sonderjysk Lokalhistorie.

og Erø til sin gamle farbroder, som for egen vindings skyld lod kirkerne forfalde!

På trods af den til kancelliet indsendte fortegnelse fandt der imidlertid ingen forhandlinger - eller irettesættelser - sted i de næste år. Først i 1609 blev spørgsmålet taget op igen - med udgangspunkt i klagerne fra 1605.

I begyndelsen af februar 1609 blev Axel Brahe til Elvid og Jacob Rosenkrantz til Kiærstrup i kraft af deres stillinger som embedsmænd på henholdsvis Dalum Kloster og Nyborg Slot pålagt at tage til Sønderborg og forhandle med Hans den Yngre angående hans ulovlige indtrængen i den gejstlige jurisdiktion på Als og Ærø. I instruksen blev det udtrykkeligt nævnt, at det drejede sig om at undgå, at der opstod en præcedens med negativ virkning for kronen. Hans den Yngre skulle sørge for at rette op på klagerne. Kneb det med velvilligheden, skulle Brahe og Rosenkrantz oplyse, at kongen havde midler, som også kunne løse dét problem! ${ }^{127}$

Ligesom ved de tidligere rejser til Als og Ærø blev der lavet en udførlig rapport om forlobet. ${ }^{128}$

Om aftenen den 21. februar 1609 ankom de to embedsmænd til Als. Tidligt næste morgen blev Brahe og Rosenkrantz hentet til Sønderborg Slot. Efter at have hørt en prædiken i kirken kom de i audiens hos Hans den Yngre. Her blev 
kongens klagepunkter fremført: hertugen blandede sig i den gejstlige jurisdiktion over Als og Ærø, selv om han havde givet afkald på denne rettighed. Han og hans undersåtter havde stor gæld til kirkerne som Christian IV ønskede betalt én gang for alle. En gård på Als havde givet landgilde til Graabrødre Kirke i Odense og en gård på Ærø havde givet sin landgilde til Sankt Jørgens hospitalet ved Svendborg. Hertugen havde imidlertid tilbageholdt landgilden, hvilket kongen nu ønskede bragt i orden. Præsten i Notmark, Frederik Jørgensen, var blevet fradømt jord, der fra arilds tid beviseligt havde hørt til præstegården. Også dette misforhold bad kongen Hans den Yngre om - uden forhalingsmanøvrer - at rette. Christian IV ønskede, at kirkeværgerne selv fik lov at sælge kirkekornet så dyrt som muligt, så restancer som hidtil kunne ophøre. ${ }^{129}$

Via en af hoffets tilknyttede jurister, dr. Isaac Memmius, bad hertugen om at få kongens anliggende på skrift, hvilket Brahe og Rosenkrantz med det samme indvilligede $i$, hvis Hans den Yngre til gengæld ville give skriftligt svar. Det ville hertugen gerne. Men Hans den Yngre ville imidlertid ikke give afkald på noget, der var hans eget. Han henviste til et mageskiftebrev, som var indgået med hans nu afdøde broder, Frederik II. Embedsmændene svarede, at kongen jo ikke ønskede at få andet end det han rettelig tilkom. ${ }^{130}$

Næste dag gjorde hertugens sekretær, Johannes Hildesheim, opmærksom på, at ikke alle præsters klager var berettiget. Hertugen ville derfor samle fogeden og nogle gamle bønder, som ville vide, hvad der var ret og uret.

Den 25. februar klokken syv om morgenen blev Brahe og Rosenkrantz hentet af Isaac Memmius og Johannes Hildesheim. Da de kom til slottet var alle de alsiske præster til stede såvel som bønder og fogeder. Klagerne blev læst op og hertugen svarede skriftligt på hver klage. Næste dag var præsterne fra Ærø mødt og samme procedure gentog sig.

Da forhandlingerne var afsluttet, blev Brahe og Rosenkrantz inviteret til at spise aftensmad på slottet, hvor de efterfølgende overnattede. Næste dag efter morgenmåltidet kom marskallen sammen med dr. Memmius og Hildesheim ind til de to gaster med Hans den Yngres skriftlige svar til kongen. Svaret var først og fremmest, at ikke alle kritikpunkter var berettiget. Hertugen håbede desuden, at de præster, som var fremkommet med uretmæssig kritik, blev straffet. ${ }^{131}$ Derefter tog de kongelige udsendinge hjem igen. ${ }^{132}$

En egentlig afslutning på forhandlingerne i 1609 synes der ikke at eksistere. Christian IV havde - endnu en gang - sat Hans den Yngre på plads og tilsyneladende så eftertrykkeligt, at der ikke for alvor blev anledning til yderligere forhandlinger og undersøgelser i Hans den Yngres sidste år. Hertugens fremgangsmåde efter Frederik Ils død i 1588 havde været klart mere hensynsløs end tidligere - både $\mathrm{i}$ argumentation og $\mathrm{i}$ handling. Derfor måttte der også gribes kraftigere ind. 
Én ting var, at kirkerne var blevet forholdt deres kirkekorn. Det var Hans den Yngre ikke alene om - det gjorde adelen også. Værre var det, at hertugens egne fogeder fradømte præsterne jord, som gennem mange år havde hørt til kirker og præstegårde. Her udnyttede hertugen simpelthen sin indflydelse på den dømmende magt så groft, at det ikke ligger fjernt at tale om magtmisbrug.

I det hele taget bærer den hertugelige kirkepolitik præg af desperation efter Frederik IIs død. Indtil kongens død i 1588 var der to - nemlig kongen og hertugen - til at udlægge og fortolke striden. Derefter var Hans den Yngre alene og mange argumenter synes præget af, at Frederik II ikke kunne svare igen på de hertugelige synspunkter. Det gjaldt ikke mindst Hans den Yngres påstand om, at kirkehøjheden i 1588 var tæt på at blive overladt til hertugen. Kongens politik viste klart noget andet gennem alle årene, men ingen kunne jo vide, hvad de to brødre måtte have talt om indbyrdes i kongens sidste tid. Imidlertid var der ingen vaklen blandt rigsråderne og formynderstyret. De kendte kirkestriden og vidste, at ethvert middel ville blive taget $\mathrm{i}$ brug for at få ændret den gældende ret.

Tilsvarende var hertugens forsøg på i 1590 at overtage kirkeregnskabsforhøringen på Als og Ærø udtryk for en nærmest panikagtig hungren efter kirkehøjheden. Skulle han nogensinde gøre sig håb om at få den gejstlige jurisdiktion - som han gentagne gange havde accepteret ikke at gøre krav på! - så skulle det snart være. Perioden under formynderstyret var oplagt, da den danske kongemagt $\mathrm{i}$ disse år stod svagere $\mathrm{i}$ kraft af kongens mindreårighed. Hans den Yngre tilhørte desuden familiens ældste generation og har'måske også af den grund følt sig berettiget til at benytte en mere vidtgående taktik over for en ung og uprovet Christian IV. Den opfattelse har i hvert fald sandsynligheden for sig - også når man betragter årene 1605-1609, hvor de sidste egentlige forhandlinger fandt sted.

\section{Hertug Hans den Yngres sidste år}

Forhandlingerne i 1609 var ikke faldet ud til Hans den Yngres fordel, idet kongens overhøjhed kom til udtryk flere gange i de følgende år. I 1613 gav Christian IV en tiendelov for øerne. I 1615 udgik en instruktion om kirkeforstanderskaberne og tiendevæsenet på øerne. ${ }^{133}$ Kongens brug af den gejstlige jurisdiktion var altså uanfægtet.

Trods denne tilsyneladende ro om den gejstlige jurisdiktion må der bag facaden have været en begyndende uro under opsejling. Det ses af et brev fra den 27. juni 1617 som Jacob Ulfeldt skrev til kongens kansler, Christen Friis til Kragerup. Ulfeldt - som siden 1610 havde været lensmand på Nyborg Slot skrev, at Hans den Yngre igen og igen havde forårsaget problemer i forbindelse 


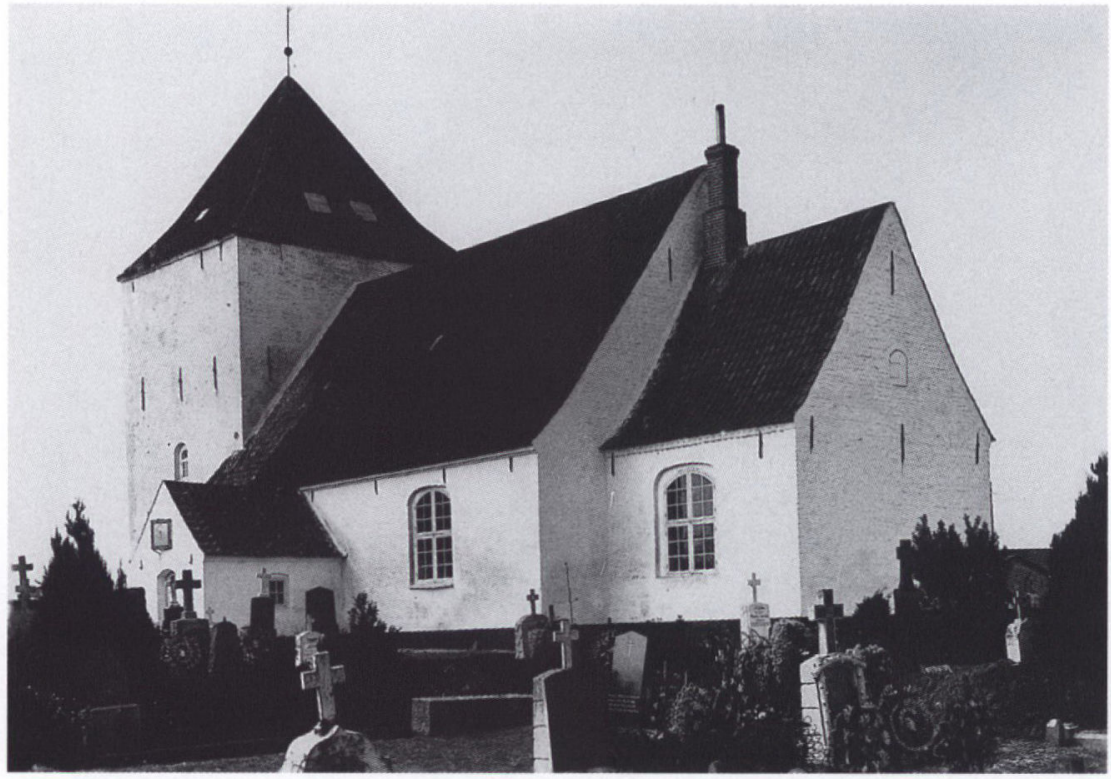

Kegnas kirke opfortes 1615 i forbindelse med bebyggelsen af Kegnas. Kirken er opkaldt efter Hans den Yngres navnebroder Johannes (Døberen). Nykirke på den anden side af Flensborg fjord byggedes i 1621-1622 efter de samme tegninger. Til dette byggeri bragte bonderne fra Sundeved og Als sten og tommer sammen. Foto i Institut for Sønderjysk Lokalhistorie.

med den gejstlige jurisdiktion på Als og Ærø, selv om højheden tilhørte den danske krone. Ulfeldt anmodede Christen Friis om at overveje sagen. ${ }^{134}$

Der ses ikke at være blevet foranstaltet hverken større eller mindre undersøgelser eller irettesættelser overfor Hans den Yngre på baggrund af Ulfeldts skrivelse. Brevet var muligvis den umiddelbare anledning til, at kongen en måned senere - den 19. juli 1617 - præciserede sin tiendelov af $1613,{ }^{135}$ men det kan ikke dokumenteres.

Ved kongelig lov af 25. juli 1621 blev kirke- og tiende-væsenet på Als ordnet med Hans den Yngres samtykke. ${ }^{136}$

Dermed var kronens højhedsret endeligt fastslået og den mangeårige strid var bragt til ende. Selv om hertugen havde ført en livslang strid med talrige diskussioner, brevvekslinger, undersøgelser og påtaler til følge, så var og forblev kirkehøjheden på Als og Ærø uopnåelig for Hans den Yngre.

Hertug Hans den Yngre døde på Glücksborg Slot den 9. oktober 1622 i en alder af 77 år. Ifølge testamentet af 11 . februar 1621 blev det lille fyrstendømme herefter delt i fem dele. Testamentet nævner intet om den gejstlige jurisdiktion, ${ }^{137}$ men delingen efter Hans den Yngres død - ligesom de senere delinger - 


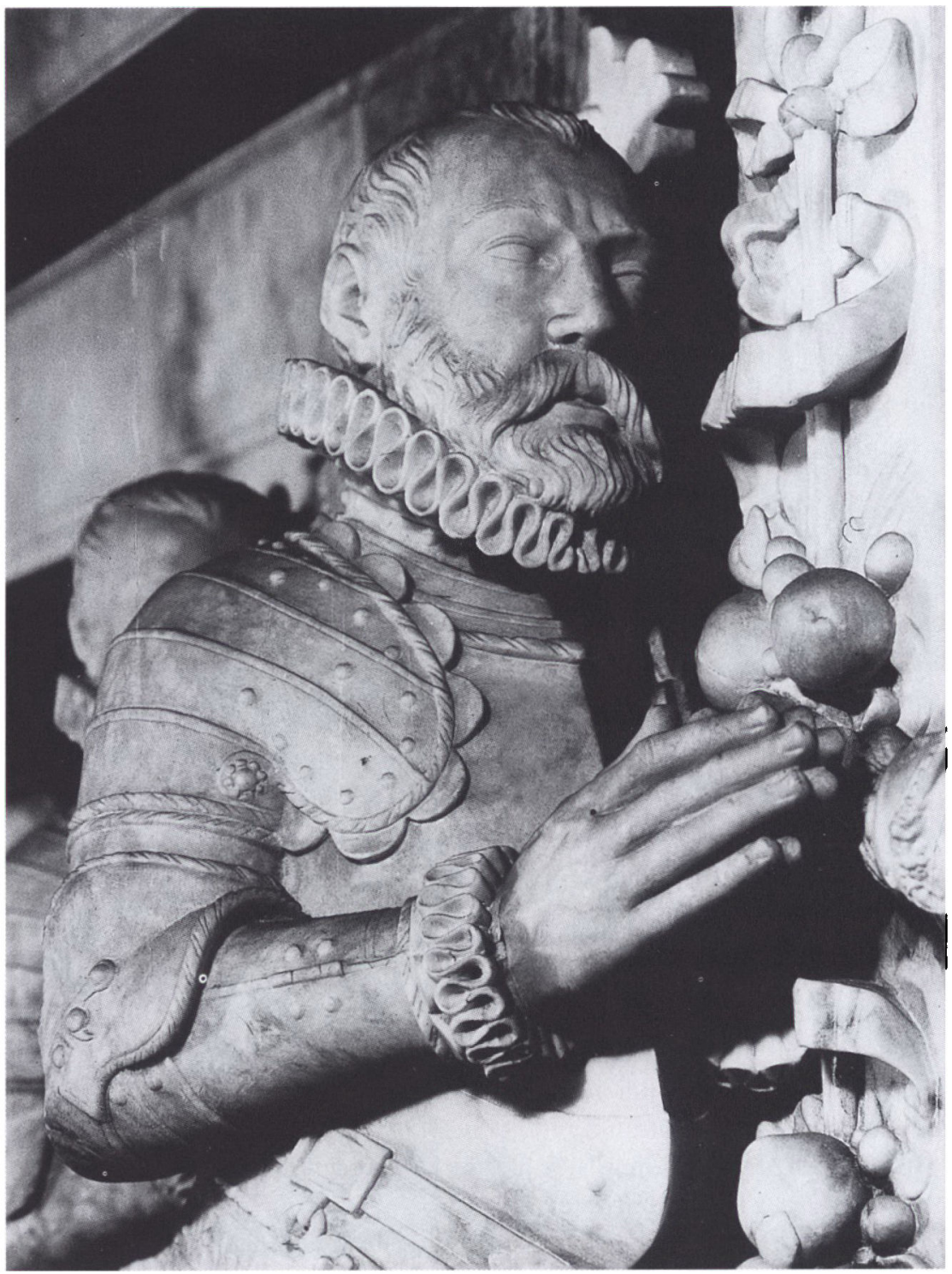

Hans den Yngre pd epitafiet i slotskapellet $i$ Sonderborg. Foto i Museet på Sonderborg Slot.

betød, at hertugerne blev stadig mere ubetydelige. Ingen anfægtede for alvor kronens ret til den gejstlige jurisdiktion på øerne. ${ }^{138}$ Den danske kongemagts statuerede eksempel havde vist sig tilstrækkeligt! 


\section{Konklusion}

Som det er fremgået i det foregående, var striden om kirkehøjheden over Als og Ærø ikke kun en sag mellem enkedronning Dorothea og Frederik II. Sagen var aktuel i alle Hans den Yngres år som hertug af Sønderborg.

Gennem hele fremstillingen er det gået som en rød tråd, at enkedronning Dorothea og især Hans den Yngre ønskede at have den gejstlige jurisdiktion over Als og Erø, fordi de sammenlignede sig med de øvrige hertuger i Slesvig og Holsten - samt Tyskland - som i kølvandet på reformationen havde opnået både kirke- og landshøjheden i deres områder. Denne fulde suverænitet måtte Dorothea og Hans den Yngre - $\mathrm{i}$ deres lutherske selvforståelse - nødvendigvis også have.

Livet igennem arbejdede Hans den Yngre på at blive anerkendt som regerende fyrste. Det lykkedes imidlertid aldrig, og hertugen følte det som en svækkelse af den nødvendige autoritet og myndighed over for undersåtterne. Hertugen havde med andre ord behov for at cementere sin status som fyrste! Striden om den gejstlige jurisdiktion over Als og Ærø skal ses i denne sammenhæng: kirkehøjheden skulle bidrage til at fuldstændiggøre det fyrstelige ideal - eller kompensere for de øvrige mangler.

Hertugen blev hele sit liv ved med at kæmpe for kirkehøjheden. Helt desperat blev optrapningen af striden umiddelbart efter Frederik IIs død i 1588. Hans den Yngre ville - ligesom Dorothea ville det i 1560'erne - have kirkehøjheden inden han døde, uanset hvilke midler der end skulle bruges. Over for den danske krone kæmpede han imidlertid forgæves.

I betragtning af de mange års forhandlinger er det ikke noget imponerende resultat Hans den Yngre opnåede: den gejstlige jurisdiktion over Sønderborg samt over de kirker, som han siden hen måtte ønske at bygge. Håbet om senere at få mere - som denne indrømmelse gav Hans den Yngre - brast. Bortset fra højheden over Egen Kirke, som hertugen arvede i 1582, og Kegnæs Kirke, som han lod bygge i 1615, forblev resten af Als og hele Arø fortsat under dansk kirkehøjhed. Ved Hans den Yngres død i 1622 var striden om den gejstlige jurisdiktion tilendebragt med kongen som den sikre vinder.

Først 200 år senere - i 1819 - udskittes Als og ÆErø fra Fyns Stift. Herefter var øerne et selvstændigt bispedømme, indtil det atter opløstes i forlængelse af tabet af hertugdømmerne i 1864. 


\section{KILDER OG LITTERATUR}

\section{Utrykte kilder:}

\section{Rigsarkivet:}

Danske Kancelli: 1. departement. Registrantsager nr. 01-80. 1801. Bilag til kgl. reskript 16/1-1801.

Danske Kancelli. Indkomne Breve. B 160: Jacob Ulfeldt til Christen Friis, dat. 27/6-1617.

Håndskriftsamlingen V.Q.78: Christian 4.s instruks om den gejstlige jurisdiktion på Als og Ærø 1589.

Håndskriftsamlingen X.E.11: Om den kirkelige overhøjhed over Als og Tørninglen.

Ministeriet for Kirke- og Undervisningsvæsenet: Ekspeditionskontor for Kirkevæsenet. 1848-1864. Akter vedr. administrationen af kirkerne på Als og Ærø. 06/1 3801.

Ministeriet for Kirke- og Undervisningsvasenet: 1. Kontor. 1907-1908. Kommission af 14.8.1907 angående kirkerne pả Erø. 199/290.

Sønderjyske Fyrstearkiver: Hans den Yngre. Pergamentsbrev nr. 6. 6/3-1584. Mageskifte mellem Frederik 2. og Hans d. Yngre, hvorved hertugen får det kongelige gods på Als og Erø, hvorimod kongen får hertugens gods i Haderslev Amt.

Sønderjyske Fyrstearkiver: Hans den Yngre. Sager på papir. 8. 1571-1579, 1590. Akter vedr. striden mellem kongen og Hans den Yngre om den kirkelige overhøjhed over Als og Erø og en del bønder sammesteds. I-II.

Sønderjyske Fyrstearkiver: Hans den Yngre. Sager på papir. 9. Akter vedr. mageskifterne med kongen 1579 og 1584.

Tyske Kancelli Indenrigske Afdeling: A(-1670). 98 I-II. Akter vedr. forhandlinger med enkedronning Dorothea og Hans den Yngre om den gejstlige jurisdiktion på Als og Ærø m.m. 1567, 1571-1575, 1579-1591, 1609.

Landsarkivet i Odense:

Fyns Bispearkiv: Arø Provstis breve 1584-1740.

Landsarkivet i Aabenraa:

Fyns Bispearkiv: Alsø herreders breve 1583-1785, nr. 217.

Trykte kilder:

N. Falck: Sammlung der wichtigsten Urkunden, welche auf das Staatsrecht der Herzogthum Schleswig und Holstein Bezug haben, Kiel 1847.

Kancelliets Brevboger vedrorende Danmarks indre Forhold, København $1885 \mathrm{ff}$.

L. Laursen: Danmark-Norges Traktater 1523-1750 med dertil horende Aktstykker, bd. I: 1523-1560, København 1907; bd. II: 1561-1588, København 1912.

L. Laursen(udg.): Kronens Skøder paa afhandet og erhvervet Jordegods i Danmark, bd. 1 (1535-1648), København 1892.

Holger Fr. Rørdam: Danske Kirkelove, 3 dele, København 1883-89.

C. F. Wegener(udg.): "Dronning Dorotheas Breve«, i: Aarsberetninger fra det kongelige Geheimearchiv, 3. bind, København 1861-65.

\section{Litteratur:}

C. F. Allen: Det danske Sprogs Historie i Hertugdommet Slesvig eller Sonderjylland, bd. 1, København 1857.

Otto Fr. Arends: Gejstligheden i Slesvig og Holsten fra Reformationen til 1864. Personalhistoriske Undersegelser, 3 bd., København 1932.

Betankning afgivet of den af Ministeriet for Kirke- og Undervisningsvasenet den 14. August 1907 nedsatte Kommission til at tage de arøske Kirkers Formueforhold m.m. under Overvejelse, København 1908.

Dansk biografisk Leksikon, Kobenhavn 1979ff.

Kr. Erslev: Augustenborgernes Arvekrav. En historisk Redegorelse for den senderborgske Hertuglinies arveretlige Stilling $i$ Hertugdommerne, København 1915. 
Henrik Fangel \& Jørgen Slettebo: Adel og hertuger pd Als og Sundeved, Fra Als og Sundeved, hefte 57, 1979.

Ernst Feddersen: Kirchengeschichte Schleswig-Holsteins, bd.II: 1517-1721, Kiel 1938.

H. V. Gregersen: Reformationen i Senderjylland, Aabenraa 1986.

H. V. Gregersen: Slesvig og Holsten for 1830, Kobenhavn 1981.

Prins Hans af Glüksburg: Nachrichten aus dem Leben des Stammvaters des Sonderburger Hauses des Herzogs Johann oder Hans des Jüngern von Schleswig Holstein Sonderburg geb. 25 März 1545 + 9 Octbr 1622. Nach Akten und Briefen aus dem Königlichen Geheimen Archive zu Copenhagen, København 1877, utrykt (Kongehusarkivet: Prins Hans af Glücksburgs arkiv. C VIII 8 [kronet SHS]).

Karl Hansen: Hertug Hans den Yngre i Sonderborg skildret meest efter utrykte Kilder, Frederiksberg 1881, utrykt (Det kongelige Bibliotek, Ny kongelig Samling 2266, 4 to).

F. Hartung: "Der Deutsche Territorialstaat des XVI. und XVII. Jahrhunderts nach den fürstlichen Testamenten«, i: Deutsche Geschichtshlätter XIII, Hannover 1912, pp. 265-284.

Holger Hjelholt(udg.): Sonderborg Bys Historie, bd. 1, Sønderborg 1960.

J. R. Hübertz: Beskrivelse over Arr. Et historisk, topografisk Forsøg, København 1834.

H. N. A. Jensen: Versuch einer kirchlichen Statistik des Herzogthums Schleswig, 2 bd., Flensburg 1840-1841.

H. N. A. Jensen \& A. L. J. Michelsen: Schleswig-Holsteinische Kirchengeschichte. Nach hinterlassenen Handschriften, bd. 3, Kiel 1877.

Jørgen Steen Jensen: Hertug Hans den Yngre. En biografi. Katalog over monter og fortegnelse over montfund, Fra Als og Sundeved, bd. 50, 1971.

Ellen Jørgensen \& Johanne Skovgaard: Danske Dronninger. Fortallinger og Karakteristikker, København 1909-10.

F. v. Krogh: Beiträge zur älteren Geschichte des Hauses Holstein-Sonderburg, Berlin 1877.

Vilh. la Cour m.fl.(red.): Senderjyllands Historie fremstillet for det danske Folk, II. bind. Tidsrummet 1241-c.1600, København 1937-39.

E. Ladewig Petersen: anm. af Jørgen Steen Jensen: Hertug Hans den Yngre (1971), i: Historisk Tidsskrift, 12.r.6, København 1973, pp. 555-559.

E. Ladewig Petersen: »Norgesparagrafen i Christian III's håndfæstning 1536. Studier over det 16. århundredes fortolkning «, i: Historisk Tidsskrift, 12.r.6, København 1973, pp. 393-464.

E. Ladewig Petersen: Veritas et honor regis. Studier over Niels Slanges kilder og kildebehandling $i$ hans fremstilling af Christian IV.' historie, Odense 1974.

Peter Langendorf: "Herzog Johann der Jüngere zu Schleswig-Holstein-Sonderburg«, i: Nordelbingen. Beiträge zur Heimatforschung in Schleswig-Holstein Hamburg und Lübeck, bd. 3, Flensburg 1924, pp. $341-410$.

C. C. Lorenzen: "Hertug Hans den yngre og hans Slægt. Et Blad af Sønderjyllands Fortidshistorie«, i: Samlinger til jydsk Historie og Topografi, X. bind, Aalborg 1884-85, pp. 305-352.

Thorkild C. Lyby: "Luthers syn på forholdet mellem kristendom og samfund «, i: Hans Jørgen Frederiksen(red.): Reformationsperspektiver (Acta Jutlandica LXII:3), Aarhus 1987, pp. 9-46.

Henning Mathiesen: „Under adels- og hertugstyre. Hørup og Ulkebøl sogne indtil ca. 1670«, i: Sonderjyske Arboger, Aabenraa 1994, pp. 9-44.

Hugo Matthiessen: „Enkedronning Dorothea paa Koldinghus«, i: Vejle Amts Aarbøger, København 1908, pp. 1-90.

Erik Moltke m.fl.(red.): Danmarks Kirker. Sønderjylland. Bind XXIII, København 1961.

Otto Norn m.fl.: Senderborg Slot. Historie og bygning, København 1963.

Erich Pontoppidan: Annales Ecclesia Danica Diplomatici, bd. III, København 1747.

Holger Fr. Rørdam: »Bidrag til Sønderjyllands Kirkehistorie i det 16de Aarhundrede«, i: Kirkehistoriske Samlinger, 3 rk. I, 1874-77, pp. 45-113 og 687-741.

Erik Schalling: Kyrkogodset i Skàne, Halland och Blekinge under dansk tid, Stockholm 1936.

Winfried Schulze: "Gerhard Oestreichs Begriff "Sozialdisziplinierung in der fruhen Neuzeit««, i: Zeitschrift für historische Forschung, 14. Band, Berlin 1987, pp. 265-302.

P. Severinsen: Folkekirkens Ejendoms-Historie, København 1920. 
C. L. E. v. Stemann: Geschichte des öffentlichen und Privat-Rechts des Herzogthums Schleswig, 2. del, Kabenhavn 1866.

C. L. E. v. Stemann: Schleswigs Recht und Gerichtsverfassung im siehenzehnten Jahrhundert. Nach den Gerichtsprotokollen, Schleswig und Flensburg 1855.

C. L. E. v. Stemann: "Zur Geschichte der geistlichen Gerichtsbarkeit und der Consistorien im Herzogthum Schleswig«, i: Slesvigske Provindsialefterretninger, Ny Række. 4. bd.. Haderslev 1863, pp. 505-552.

C. Wegener: Nogle historiske Oplysninger om Kirkehoiheden over Torninglehn, Als og Aro, Kobenhavn 1848, utrykt (RA: Hånd-skriftsamlingen X.E.11).

Hans Wullenweber: Herzog Hans der Jüngere von Sonderburg. Ein Fürstenleben und ein Zeitbild aus dem ersten Jahrhundert nach der Reformation, Aabenraa 1945.

Anvendte forkortelser:

$D B L$ : Dansk biografisk Leksikon.

DK 180I: Danske Kancelli. Bilag til kgl. reskript 16/1-1801.

$F B$ : Fyns Bispearkiv.

$K B$ : Kancelliets Brevbøger.

$L A O$ : Landsarkivet i Odense.

$L A A$ : Landsarkivet i Aabenraa.

MKU 1848-64: Ministeriet for Kirke- og Undervisningsvasenet. 1848-1864. 06/1 3801.

$M K U$ 1907: Ministeriet for Kirke- og Undervisningsvæsenet. 1907-1908. 199/290.

$R A$ : Rigsarkivet.

$R D K$ : Rørdam: Danske Kirkelove.

SFHY 8-I og II: Sønderjyske Fyrstearkiver: Hans den Yngre. Sager på papir. 8. I-II.

SFHY 9: Sønderjyske Fyrstearkiver: Hans den Yngre. Sager på papir. 9.

SFHY 1584: Sønderjyske Fyrstearkiver: Hans den Yngre. Pergamentsbrev nr. 6. 6/3-1584.

TKIA 98-I og II: Tyske Kancelli Indenrigske Afdeling: A(-1670). 98 I-II.

\section{NOTER OG HENVISNINGER}

1. Wegener, $1848,6 \mathrm{ff}$.

2. Gregersen, $1986,120$.

3. la Cour m.fl.(red.), 1937-39, 345 f.

4. Laursen, bd. I, 1907, 488ff.

5. Gregersen, 1986, $234 \mathrm{f}$.

6. Kirkehøjhedsstriden ẹ behandlet i: Wegener, 1848: Stemann, 1855, 58f; Allen, 1857, 74ff; Stemann, 1863, 514f; Stemann, bd. II, 1866, 26f; Jensen \& Michelsen, bd. 3, 1877, 107; Krogh, 1877, 17f; Prins Hans af Glücksburg, C VIII 8, 1877, afsnit 11; Hansen, 1881; Jørgensen \& Skovgaard, 1909-10, 105; Langendorf, 1924, 374ff; 389ff; Feddersen, 1938, 137; la Cour m.fl.(red.), 1937-39, 356; Hjelholt(udg.), 1960, 28; der henvises iøvrigt til mit utrykte speciale: Enkedronning Dorotheas og hertug Hans den Yngres strid med kongemagten om kirkehøjheden over Als og Aro i àrene efter 1566. Odense Universitet, januar 1996.

7. DBL, bd. 4, 1980, 19 f.

8. Matthiessen, 1908, 6.

9. Rørdam, 1874-77, 53ff; Matthiessen, 1908, 38ff.

10. Matthiessen, 1908, 71; 78ff; 84.

11. Jensen, 1971, 11; Jørgensen \& Skovguard, 1909-10, 108; Matthiessen, 1908, 25.

12. Afsnittet er $\mathrm{i}$ hovedsagen baseret på Jorgen Steen Jensens biografi af Hans den Yngre fra 1971 (især siderne 11-18) og sammes artikel i DBL, bd. 5, 1980, 549f.

13. Hertugen regerede i praksis næsten uindskrænket i sine egne besiddelser; se: Jensen, 1971, $31 \mathrm{ff}$.

14. Hartung, 1912, 269; 283.

15. Ladewig Petersen, 1973, 555ff. 
16. Jensen, 1971, 68ff; Ladewig Petersen, 1973, 558f.

17. Jensen \& Michelsen, bd. 3, 1877, 107; Wegener, 1848, 18f; Stemann, 1863, $513 f$.

18. TKIA 98-I: Frederik II til enkedronning Dorothea, dat. 14/3-1567.

19. TKIA 98-I: enkedronning Dorothea til Frederik II, dat. 23/3-1567; trykt i: Wegener (udg.), 1861-1865, $22 f$ (nr. 168).

20. TKIA 98-I: Frederik II til enkedronning Dorothea, dat. 30/7-1567.

21. Nieis Jesperssøn (1518-1587), biskop fra 1560 .

22. TKIA 98-I: enkedronning Dorothea til Frederik II, dat. 3/8-1567; trykt i: Wegener (udg.), 18611865, $27 \mathrm{f}$ (nr. 174).

23. Lyby, 1987, 25.

24. Efter reformationen i 1536 overtog den danske krone den katolske kirkes bispegods i Danmark. Tienden deltes som før $\mathrm{i}$ tre dele (til præst, kirke og biskop), men den tidligere bispetiende gik nu til kongen (kongetiende); se: Schalling, 1936, 226ff; på Als og Arø var der ingen bispetiende. Tienden deltes kun i to dele; se: TKIA 98-I: fortegnelse (tidl. signatur: xxiii 8h); trykt i: Wegener (udg.), 1861-1865, 35 (bilag 6 til nr. 174).

25. TKIA 98-I: Frederik II til enkedronning Dorothea, dat. 14/8-1567; trykt i: Wegener (udg.), 1861-1865, 29f (bilag 1 til nr. 174).

26. Wegener(udg.), 1861-1865, 31f (bilag 2, 3 og 4 til nr. 174); (findes også i resumé i: KB 15661570, 230 (14/8-1567); RDK, 2. del, 97f (nr. 128)).

27. TKIA 98-I: Frederik II til enkedronning Dorothea, dat. 14/8-1567; trykt i: Wegener (udg.), 1861-1865, 29ff (bilag 1 til nr. 174).

28. TKIA 98-I: protokol (tidl. signatur: xxiii 8g); trykt i: Wegener (udg.), 1861-1865, 32f (bilag 5 til nr. 174); med hensyn til pantegodset se også sammesteds s. 22f (nr. 168).

29. TKIA 98-I: protokol (tidl. signatur: xxiii 8g); trykt i: Wegener (udg.), 1861-1865, 33f (bilag 5 til nr. 174).

30. TKIA 98-I: enkedronning Dorothea til Frederik II, dat. 5/9-1567; trykt i: Wegener (udg.), 1861$1865,36 \mathrm{ff}$ (nr. 176).

31. TKIA 98-I: Frederik II til enkedronning Dorothea, dat. 12/9-1567.

32. TKIA 98-I: Frederik II til enkedronning Dorothea, dat. 18/9-1567.

33. TKIA 98-I: enkedronning Dorothea til Frederik II, dat. 26/9-1567; trykt i: Wegener (udg.), 1861-1865, 39 (nr. 177).

34. Enkedronning Dorothea til Frederik II, dat. 29/9-1567 og 23/10-1567; trykt i Wegener (udg.), 1861-1865, 40ff (nr. 178 og 179).

35. TKIA 98-I: Frederik II til enkedronning Dorothea, dat. 25/10-1567.

36. TKIA 98-I: enkedronning Dorothea til Frederik II, dat. 30/10-1567; trykt i: Wegener (udg.), 1861-1865, 42 ff (nr. 180).

37. TKIA 98-I: Frederik II til enkedronning Dorothea, dat. 5/11-1567.

38. KB 1571-1575, 82 (24/10-1571); RDK, 2. del, 162 (nr. 226).

39. Desuden findes i Danske Kancelli B 44 under 30. marts 1571 en dom af provsten Johannes Berendes på suspensionsstraf og tre års landsforvisning for sognepræst Jacob Land på đêrø på grund af hans gentagne grove forseelser (hor).

40. Jensen, bd. 2, 1841, 1638.

41. Berndes døde i 1596; i: Arends, bd. 1, 1932, 43.

42. TKIA 98-I: Jorde Bog aff Alss och Erøe (1571).

43. SFHY 8-I: Frederik II til Hans den Yngre, dat. 24/10-1571; kopi i: TKIA 98-I.

44. TKIA 98-I: Frederik II til Hans den Yngre, dat. 16/12-1571.

45. TKIA 98-I: Hans den Yngre til Frederik II, dat. 24/4-1572.

46. TKIA 98-1: Hans den Yngre til Frederik II, dat. 13/11-1572.

47. SFHY 8-I: Frederik II til Hans den Yngre, dat. 19/11-1572; kopi i: TKIA 98-I.

48. Langendorf, 1924, 389f; de kongelige bønder slap dog ikke fuldstændigt for hoveri. De blev rent faktisk sendt til Fyn for at hjelpe med at omgrøfte nogle ejendomme ved Nyborg Slot $\mathrm{i}$ 1578, da de alsisk-ærøske bønder ikke var så tynget af hoveri som de fynske bønder; i: KB 1576-1579, 366 (31/5-1578). 
49. TKIA 98-I: Prothocoll Der Bruderlichen vndterredung vnd Handlung ... auf dem Schlosse Dronningburg bey Persohnlicher gegenwertigkeit gehalten worden, dat. 28. april 1573.

50. På grundlag af arvedelingen fra 27/1-1564 var godskravet juridisk set uberettiget; Laursen, bd. II, $1912,113$.

51. TKIA 98-I: Hans den Yngre til Frederik II, dat. 24/4-1572.

52. TKIA 98-I: proposition (tidl. signatur: xxiii $8 \mathrm{fff}$ ); i forbindelse med selve forhandlingen i juni på Kolding Rådhus, skete der det ret pinlige, at flere af de hertugelige forhandlere drak hele natten til klokken seks om morgenen. Det betød, at Hans den Yngres sekretær, Peter Gandelfinger, klokken ni måtte gå op på rådhuset og bede om, at forhandlingerne kunne vente med at starte til klokken 13, hvilket bevilligedes fra dansk side; i: Jensen, 1971, 40.

53. SFHY 8-I: Frederik II til Hans den Yngre, dat. 8/7-1573; kopi i: TKIA 98-I.

54. TKIA 98-II: Hans den Yngre til Frederik II, dat. 9/10-1573.

55. TKIA 98-II: Odense den 27. marts 1574 (tidl. signatur: xxiii 8gggg).

56. TKIA 98-II: Frederik II til kurfyrst August og hertug Ulrik, dat. 1/7-1574.

57. Wegener, 1848, 27; Langendorf, 1924, 376.

58. SFHY 8-I: Frederik II til Hans den Yngre, dat. 24/10-1574; kopi i: TKIA 98-II.

59. Langendorf, 1924, 390.

60. KB 1576-1579, 611f (31/3-1579).

61. TKIA 98-II: Hans den Yngre til Frederik II, dat. 4/4-1579; trykt i: Stemann, 1855, $268 f$.

62. SFHY 8-II: Frederik II til Hans den Yngre, dat. 14/4-1579; kopi i: TKIA 98-II; trykt i: Stemann, 1855, 269f.

63. TKIA 98-II: Hans den Yngre til Frederik II, dat. 22/4-1579 (trykt i: Stemann, 1855, 270) og udkast til Hans den Yngres revers, april 1579 (kopi).

64. KB 1576-1579, 630ff (1/5-1579).

65. Norn m.fl., 1963, 45 .

66. RDK, 2. del, 305f (nr. 438).

67. Se fx: Stemann, 1863, 514 og 1866, 26f; Hjelholt (udg.), 1960, 28.

68. Allen, 1857, 74f.

69. Der var i samme forbindelse også strid om arveretten til Norge. Hertugerne Hans den Eldre og - især - Adolf krævede arveretten til Norge afklaret. Selv efter den slesvigske lenskonflikts losning i 1579-1580 havde Adolf ikke opgivet sine arvekrav, hvilket i 1582 kom til udtryk i et memorandum til svogeren, landgrev Wilhelm IV af Hessen; i: Ladewig Petersen, 1973, 420ff; 427ff; $455 \mathrm{ff}$.

70. Laursen, bd. II, 1912, 513ff; Erslev, 1915, $20 \mathrm{ff}$.

71. Laursen, bd. II, 1912, 596ff; Falck, 1847, 82ff.

72. SFHY 9: udkast til permutationsbrev om det haderslevske gods, udateret.

73. SFHY 9: beretning, dat. 18/12-1583.

74. TKIA 98-II: Hans den Yngre til Frederik II, dat. 20/1-1584.

75. Det er ikke lykkedes at finde brevet i original, men der er afskrevet en del af det i: Wegener, 1848, $93 \mathrm{ff}$ (note 22); Håndskriftsamlingen X.E.11: biskop Jørgen Hansen til ministeriet, dat. 14/10-1848 rummer et referat og tilsvarende i: MKU 1848-64: biskop Jørgen Hansen til ministeriet, dat. 26/12-1848 (8/1-1849).

76. TKIA 98-II: Hans den Yngre til Frederik II, dat. 11/2-1584 (kopi).

77. Det er ikke lykkedes at finde brevet $i$ original, men to af hinanden uafhængige andenhåndskilder refererer indholdet. Det gælder således MKU 1907: Diverse afskrifter m.v. vedr. kirkekassens historie, som henviser til: DK 1801: pro memoria, dat. 20/11-1800; biskop Jørgen Hansen har skrevet til ministeriet, MKU 1848-64: dat. 26/12-1848 (8/1-1849) og Håndskrift-samlingen X.E.11: dat. 14/10-1848. Se også: Betankning afgivet af den af Ministeriet for Kirke- og Undervisningsvasenet den 14. August 1907 nedsatte Kommission til at tage de areske Kirkers Formueforhold m.m. under Overvejelse, 1908, 4; Krogh, 1877, 18.

78. I alt udgjorde det tidligere fynske kirkegods 59 gårde og 26 kåd på Als og 65 gårde på Ærø, se også: Fangel \& Slettebo, 1979, 45.

79. SFHY 1584; ekstrakt om kirkehøjheden i LAO. FB: Ærø Provstis breve 1584-1740; resumé i: Laursen, 1892, 277f; uddrag om kirkehøjheden i: Stemann, 1863, $551 \mathrm{f}$. 
80. Hjelholt (udg.), 1960, 28.

81. Langendorf, $1924,376 \mathrm{f}$.

82. la Cour m.fl. (red.), 1937-39, 354; Gregersen, 1986, 234 f.

83. Severinsen, 1920, 141f; Gregersen, 1981, 253.

84. Erslev, 1915, 9.

85. Feddersen, 1938, 137.

86. Allen, 1857,75 .

87. I denne sammenhæng er det vigtigt - som påpeget af Johanne Skovgaard - at erindre, at Sønderborg i 1584 - i modsætning til de øvrige alsiske præster og bønder - mistede muligheden for kongens hjælp overfor hertugens hårde styre; i: Hjelholt (udg.), 1960, 28.

88. Provstiet er omtalt i: Allen, 1857, 75; Arends, bd. 3, 1932, 34f; Feddersen, 1938, 137 (har også en oversigt over Hans den Yngres ti kirker i de holstenske besiddelser); Jensen, bd. 1, 1840, 312ff; Jensen \& Michelsen, bd. 3, 1877, 296f; Jensen, 1971, 82; Wegener, 1848, 39.

89. Wegener, 1848, 39; Moltke m.fl. (red.), 1961, 13: kirken i Sønderborg kom ved de sønderborgske hertugers konkurs i 1667 tilbage til kronen; men adskillelsen fra Fyns Stift opretholdtes, idet kirken i 1668 lagdes under Slesvig Bispestol.

90. Moltke m.fl. (red.), 1961, 160f; 182f, 202f; 222f; $240 f$.

91. Moltke m.fl. (red.), 1961, 470; Laursen, bd. II, 1912, 607.

92. Laursen, bd. II, 1912, 606.

93. Jensen, 1971, 53.

94. Gregersen, 1986, 239; Jensen \& Michelsen, bd. 3, 1877, 296; Jensen, 1971, 49.

95. Sønderborgs særstilling har gennem tiden givet nogen forvirring. Byen er blevet betragtet som udenfor Odense Stift fra 1567 (Jensen \& Michelsen, bd. 3, 1877, 107), fra før 1564 (Lorenzen, 1884-85, 307) og fra middelalderen (Gregersen, 1986, 18f; 203f).

96. Jensen, 1971, 53f.

97. Hans den Yngre gjorde efter al sandsynlighed fordring på andel i formynderstyret, men uden succes; i: Ladewig Petersen, 1974, $51 \mathrm{ff}$.

98. TKIA 98-II: Sekretær Peter Gandelfinger og amtmand Paul Uge til rigsråderne, udat., ca. 1588 ifølge påtegning, men snarere fra foråret 1589 jvf. TKIA 98-II: Hans den Yngre til rigsråderne, dat. 20/4-1589.

99. Brevet er ikke fundet i original, men er omtalt i: Prins Hans af Glücksburg, C VIII 8, 1877, afsnit 11 .

100. TKIA 98-II: Hans den Yngre til rigsråderne, dat. 5/12-1588.

101. KB 1588-1592, 131 (27/12-1588); RDK, 2. del, 459 (nr. 598).

102. Jacob Madsen Vejle (1538-1606) biskop fra 1587.

103. Håndskriftsamlingen. V.Q.78; KB 1588-1592, 227ff (31/7-1589); RDK, 2. del, 470 (nr. 617).

104. Forhøringen af kirkeregnskaberne havde fundet sted flere gange før, men ikke i de allerseneste år, hvorfor kirkerne var begyndt at forfalde; se: KB 1576-1579, 412 (5/7-1578); 705 (2/8-1579); 768 (26/11-1579); KB 1580-1583, 300 (10/6-1581).

105. En undersøgelse af om kirkeordinansen efterlevedes, var yderst relevant på Als og Ærø, eftersom Hans den Yngre i 1576 havde tilsluttet sig svogeren, kurfyrst August af Sachsens omstridte konkordieformel, som skulle definere den rette lutherske lære. Frederik II afviste derimod skriftet og kastede bogen på ilden. I hertugens kirker var konkordiebogens formularer gældende; se: Jensen, 1971, 82ff.

106. TKIA 98-II: Hans den Yngre til sine undersåtter, dat. julen 1586.

107. Ifølge mageskiftet af 6. marts 1584; SFHY 1584.

108. Når biskoppen ingen anelse havde om denne særlige ordning fra 1584, må det skyldes, at Jacob Madsen først var blevet biskop i 1587 efter Niels Jesperssøns død samme år. I hvert fald findes der på grundlag af mageskiftet af 6. marts 1584 et ekstrakt om kirkehøjheden i: LAO. FB: Ærø Provstis breve 1584-1740.

109. TKIA 98-II: Laurits Brockenhus' og Jacob Madsens beretning, dat. september 1589 (tidl. signatur: xxiii 8ppppp); flere ting fremgik ikke af beretningen, men var punktvis opført på særlig liste; se: TKIA 98-II: »Huad widere Er bestillet aff Lauritz Brochenhusse och M. Ja- 
cob. Som Instruction icke wdj Articels Wis paa liuder och Haffuer Sit betenckende, « dat. september 1589.

110. TKIA 98-II: ekstrakt af kirkernes regnskab på Als og Erø, dat. september 1589 (tidl. signatur: xxiii 811111).

11. MKU 1907: Diverse afskrifter m.v. vedr. kirkekassens historie: „De ærøske Kirkers Forhold «.

112. SFHY 8-II: Hans den Yngres instruktion til sine gesandter, dat. 27/7-1590.

113. TKIA 98-II: Hans den Yngre til enkedronning Sophie (1557-1631), dat. 29/7-1590.

114. TKIA 98-II: Hans den Yngre til Christian IV (formynderstyret), dat. 10/8-1590.

115. På grundlag af det omtalte brev må der være tale om en fejl, når Jacob Pilegaard ifølge Arends kun var provst på Als i årene 1574-79, medens han var prast i Hørup fra 1574-1591; i: Arends, bd. 3, 1932, 37f.

116. Peter Knudsen (Petrus Canuti) er den første provst for Erø som man i dag kender til. Han var sogneprast i Bregninge 1560-1598.

117. TKIA 98-II: Hans den Yngre til provst Jacob Pilegaard, dat. 28/9-1590; LAO. FB: Ærø Provstis breve 1584-1740: Hans den Yngre til provst Peter Knudsen, dat. 28/9-1590.

118. SFHY 1584; ekstrakt om kirkehøjheden i LAO. FB: Frø Provstis breve 1584-1740; Stemann, $1863,551 f$.

119. KB 1588-1592, 473 (20/10-1590).

120. TKIA 98-II: Christian IVs instruks til Henrik Below og Albert Friis, dat. 1/11-1590 (kopi).

121. TKIA 98-II: Hans den Yngre til Christian IV (formynderstyret), dat. 11/11-1590; kladde i: SFHY 8-II; desuden en skrivelse i TKIA 98-1I, dat. 11/11-1590 (tidl. signatur: xxiii 8zzzzz); se også: Jensen, 1971, 55f; Wegener, 1848, 40ff.

122. Hertugens behov for kirkehøjheden kom i mellemtiden til udtryk i en række breve til biskoppen i Odense; se: LAO. FB: Ærø Provstis breve, dat. 13/6-1591; 22/4-1594; 17/4-1597; 16/8-1597; 26/11-1600 (kopi); LAA. FB: Alsø herreders breve 1583-1785, dat. 8/12-1601.

123. KB 1603-1608, 262 (13/3-1605).

124. Jensen, 1971, 46: »... hyppigt tales om bytning og skiftning af kirkejorden mellem bønderne. Selvom det kan have generet præsterne .... har en sådan udskiftning dog vel været til gavn for bonderne.«.

125. Severinsen, 1920, 22f; Mathiesen, 1994, 36.

126. TKIA 98-II: wRegisteriung och fortegnelse paa huis wrett Brøst oc Besueringer som sougnneprèsternne, Capelanner Deignne oc Kiercketiener paa Alsøe och Errø Beklagett Haffuer Inn Aprilis Anno 1605« (ligger i samme læg som forhandlingerne 1609).

127. KB 1609-1615, 25f (2/2 og 3/2-1609).

128. TKIA 98-II: Axel Brahes og Jacob Rosenkrantz' beretning, udat. (1609).

129. Klagepunkterne fremgår ikke af selve Brahes og Rosenkrantz' beretning, men i det brev med klagepunkterne som hertugen efterfølgende bad om; i: TKIA 98-II: februar 1609 (tidl. signatur: xxiii 8bbbbbb).

130. Der er antagelig tale om mageskiftet af 6. marts 1584. Det i 1584 mageskiftede gods var fuldt accepteret af rigsrådet som Hans den Yngres retmassige ejendom; i: KB 1593-1596, 725f (12/ 8-1596).

131. TKIA 98-II: Hans den Yngre til Christian IV, dat. 27/2-1609.

132. TKIA 98-II: Axel Brahe og Jacob Rosenkrantz' beretning, udat. (1609); undersøgelsen i 1609 er bemærket i: Krogh, 1877, 17f; desuden kort og lidt fejlagtigt beskrevet i: Hübertz, 1834, 44.

133. Wegener, 1848, 45ff; Wegeners oplysninger stammer fra: Pontoppidan, 1747, 726f,

134. Danske Kancelli B 160: Jacob Ulfeldt til Christen Friis, dat. 27/6-1617.

135. Pontoppidan, 1747, 726.

136. Pontoppidan, 1747, 726f; Wegener, 1848, 47; Jensen, 1971, 56; lovene af 3. september 1613 og 25. juli 1621 samt Ulfeldts instruktion fra 1615 og kongens uddybning af 1613-loven af 19 . juli 1617 burde være i: RA. TKIA. Patenten og Inländisch Registratur, men er gået tabt.

137. Testamentet findes trykt i: Falck, 1847, 101ff.

138. Wegener, $1848,47 \mathrm{f}$. 